\title{
Scoping paper on industry in Senegal
}

Fatou Cissé, ${ }^{1}$ Ji Eun Choi, ${ }^{2}$ and Mathilde Maurel $^{3}$

December 2014 
Abstract: Senegal is a typical sub-Saharan economy, which conducted an import substitution policy over 1960-86, followed by a policy of support for the private sector and liberalization of the economy. It suffers from a low level of economic development, hindering the process of economic diversification, and translating into an over-concentration of its exports and production. Through a careful analysis of the main advantages and drawbacks of the Senegalese economy, this scoping paper emphasizes the key obstacles to unleashing prosperity in the country: electricity supply and quality, and the educational system.

Keywords: export and production concentration, industrial policies, key obstacles to growth JEL classification: $\mathrm{O} 55$

Acknowledgements: This paper is one of a series of studies on industrial development in Africa produced in collaboration between the Africa Growth Initiative at Brookings, the African Development Bank (AfDB), and UNU-WIDER under their joint project 'Learning to Compete' (L2C).

Acronyms: given at the end of the document.

${ }^{1}$ Consortium Pour la Recherche Economique et Sociale (CRES); ${ }^{2}$ Oxford University; ${ }^{3} \mathrm{CES}$, Université Paris 1; corresponding author: fcisse@cres-sn.org

This study has been prepared within the UNU-WIDER project 'Learning to Compete: Accelerating Industrial Development in Africa', directed by John Page.

Copyright (C) AfDB 2014

ISSN 1798-7237 ISBN 978-92-9230-878-0 https://doi.org/10.35188/UNU-WIDER/2014/878-0

Typescript prepared by Liisa Roponen at UNU-WIDER.

UNU-WIDER gratefully acknowledges the financial contributions to the research programme from the governments of Denmark, Finland, Sweden, and the United Kingdom.

The World Institute for Development Economics Research (WIDER) was established by the United Nations University (UNU) as its first research and training centre and started work in Helsinki, Finland in 1985. The Institute undertakes applied research and policy analysis on structural changes affecting the developing and transitional economies, provides a forum for the advocacy of policies leading to robust, equitable and environmentally sustainable growth, and promotes capacity strengthening and training in the field of economic, and social policy-making. Work is carried out by staff researchers and visiting scholars in Helsinki and through networks of collaborating scholars and institutions around the world.

UNU-WIDER, Katajanokanlaituri 6 B, 00160 Helsinki, Finland, wider.unu.edu

The views expressed in this publication are those of the author(s). Publication does not imply endorsement by the Institute or the United Nations University, nor by the programme/project sponsors, of any of the views expressed. 
Promoting the development of the manufacturing sector can be a key to achieving sustainable development. It is indeed in the manufacturing sector that learning effects, technological innovations, diversification, are most likely to occur. While small economies cannot benefit from scale economies because of the small size of their internal market, trade openness is a powerful driver of industrial development. The strategy of openness is successful when it is based upon high competitiveness, which reinforces the profitability of the manufacturing sector.

But trade liberalization was not at the core of the development policies implemented in many developing countries, which opted for import substitution policies aiming at favouring the emergence of dynamic comparative advantages. This was particularly the case in Senegal, which, from the date of its independence, adopted several interventionist state policies to promote the industrial sector.

The aim of this scoping paper is to analyse the Senegalese manufacturing sector. Section 1 explores the evolution of the policies of industrial development since 1965. Section 2 depicts the structure of the industrial sector, sectoral composition at the 2-digit ISIC level, size distribution, employment, ownership, share of foreign direct investment (FDI), export contribution as well as sunrise and sunset industries. Section 3 analyses total factor productivity (TFP), its features across industries, as well as the patterns of productivity change. Its aims at relating TFP with 'fundamentals' for industrial development: availability of electricity (both in terms of quantity and quality), education level of a production worker, trade policy, amongst others. Section 4 discusses the emerging policies issues and sums up the current main problems that the industrial development faces in Senegal.

\section{Background: trade policy reforms and manufacturing performances in Senegal}

Industrial policy in Senegal, as the set of measures aiming to promote the transformation of primary products inside the country, has been marked, first of all, by a strong desire of the state to counter divestment pressures associated with the shrinking domestic market following accession to national sovereignty. In fact, ex-French colonies were engage in processes to industrialize their economy. Typical import substitution industrialization policy instruments (tariff and non-tariff barriers) were established, along with complementary measures (creation of free trade zones and investment codes) to step in for the still-nascent private sector.

Starting in the mid-1980s, the arrival of structural adjustment programmes led to economic liberalization processes, which resulted in the closure of many firms which faced competitiveness pressures in a context of an overvalued FCFA. The liberalization process was stalled by 1989 and did not pick up significantly until 1994, following a 50 per cent devaluation of the FCFA foreign exchange rate. However, this massive devaluation occurred after a long period of currency overvaluation and thus cannot be explicitly interpreted as part of a programme to implement an export promotion policy.

The second half of the 1990s saw the establishment of a new economic and monetary union with the goal of accelerating convergence and integration of West African countries with the FCFA in common, and which worked towards rationalization of the tariff barrier and elimination of nontariff barriers. Greater awareness of the social dimensions of adjustment developed through the 1990 s, leading to a second generation of reforms based on the development of human capital and infrastructure. 
The January 2005 introduction of work on the Accelerated Growth Strategy (SCA) would ultimately integrate industrial policy through a cross-cutting state intervention initiative to promote private sector development by establishing a business environment with international standards and by facilitating collaboration for the purpose of innovation through a framework commonly referred to as the cluster approach, intended to support the development of promising sectors.

In summary, Senegal conducted import substitution policy over 1960-86, largely by default, followed by a policy of support for the private sector based on liberalization of the economy.

\subsection{The evolution of the Senegalese industrial policy}

Nearly all of the newly independent countries in the region began with import substitution industrialization policies which protected nascent industrial sectors. Senegal primarily used these policy instruments during the 1960s to preserve the industrial base inherited from the colonial era.

\section{From import substitution to economic liberalization}

Over 1961-69, during the first two economic and social development plans, import substitution industrialization was prioritized. Tariff and non-tariff barriers protected large enterprises which were created by mobilizing large amounts of (often public) capital. By 1970, an alternative policy emphasized the development of small and medium business through the creation of the National Company for Industrial Research and Development (SONEPI) in 1969, followed by the Dakar Industrial Free Trade Zone (ZFID) in 1974. SONEPI is primarily responsible for technical support for private initiatives and gives substance to state industrial policy, particularly by developing industrial areas in regional capitals.

\section{Tariff protection}

Prior to the 1979 tax reform, taxes on imports included customs tariffs, statistical taxes and flatrate taxes, making the tax system complex with a diversity of taxbases making it necessary to adopt a no less complex system of exemptions which benefitted firms transforming primary products such as peanuts, imported wheat, textile fibres and fish into consumption goods. This tariff system had a dual purpose: to procure resources for the state and protect domestic firms. The second of these was reinforced by significant and highly deterrent tariffs.

\section{Quantitative restrictions}

Quotas, prior authorizations and prohibitions against the import of certain good conferred quasimonopoly situations upon beneficiary firms. Moreover, domestic producers in certain sectors benefitted from addition protection against imports through special conventions and memoranda of understanding and administrative pricing (initially used to address undervaluation of declared imports). However, exporting firms had to pay a statutory tax, a transaction tax, a statistical tax, and a market research and packaging tax (only for peanuts), thus increasing the anti-export bias in import protection measures.

The investment code

Senegal established its first investment code in 1962 to benefit firms which contributed to achievement of objectives of the strongly import substitution-oriented development plan. Beneficiary firms had major tariff and tax exemptions which would remain essentially unchanged, whether considering tax rates or the total tax take, for a full 25 years. The code was changed in 1965, lowering the required investment from 1 billion FCFA to 500 million FCFA and expanding tariff and tax exemptions on replacement parts, in addition to deferred taxes on imported inputs. In 1977, a new law came into force with the goal of densifying the industrial base through 
promotion of small and medium enterprises (SME). With this law, there were now two tax codes: the grand code for large firms and the petit code for businessmen with initial investments under 20 million FCFA.

\section{The Dakar Industrial Free Trade Zone}

The Dakar Industrial Free Trade Zone (ZFID) was established in 1974 to accommodate firms active in industry, assembly and transformation for export, as well as complementary service firms. These authorized firms were exempted from taxes on corporate profits, taxes on wages and all indirect domestic taxes on production. In terms of tariffs, they did not pay tariffs and taxes on imports of capital goods, equipment, primary materials and other semi-finished inputs. Free trade zones were introduced in 1991, and firms benefitted from all the advantages conferred upon those in the ZFID without having to set up there. Exporting firms benefitting from the free trade zone or ZFID frameworks were only to face a corporate tax of 15 per cent starting in 1995.

\section{Industrial zones}

The idea of industrial zones appeared in 1965, but was not the object of any financing agreement until the 1975 agreement between the governments of Senegal and Germany, which led to the 1978 creation of the Dakar Industrial Zone Corporation. The Senegalese state also created industrial zones in other regional capitals, albeit with varying success. SMEs operating in these industrial zones received assistance from management firms in addition to major tax advantages. In particular, they benefitted from a five-year exemption in Dakar and a seven-year exemption in other regions, from corporate taxes, and from various taxes on equipment and materials not manufactured or otherwise produced in Senegal, as well as from taxes on replacement parts for this equipment, activities relating to training or the expansion of firms, and services offered by management firms. The management firms in the industrial zones ensured that firms in the zones had economic and technical assistance in addition to developing land and equipping industrial production sites, provided legal and administrative assistance to obtain credit from financial and banking institutions, and supported marketing of products and research of public procurement of goods and services. By the early 1980s, the process of industrialization through the above measures proved to have many weaknesses: (i) the import substitution policy had reached its limits in a small and overprotected market; (ii) weakened benefits from natural resources and the export crisis left traditional export sectors (peanuts, phosphates, fish) with no prospects for recovery; (iii) high effective protective barriers (25-300 per cent) had perverse effects through lost competitiveness and high rigidities against adaptation; (iv) state intervention proved excessive and costly. Industrial growth after 1980 generally ranged from 0-2 per cent, as opposed to 4-5 per cent in the preceding decade.

\section{Adjustment policies and liberalization of the economy}

The 1970s world economic crisis arrived in Senegal with the 1980-81 collapse of macro-financial stability, exacerbated by the return of the drought cycle. Faced with a growing deficit of resources, the state appealed to Bretton Woods Institutions at the cost of more orthodox policy based on fiscal consolidation and the use of market forces to govern access to resources and their use. The adjustment policies were based on four pillars: (i) management of aggregate demand with the dual goal of controlling inflation and reducing the balance of payments deficit; (ii) restoration of market forces in determining allocations and prices of resources, (iii) opening of the economy to the outside; and (iv) withdrawal of the state and consolidation of public finances.

In 1979, the year of the first stabilization programme, the state was to simplify and reduce import tariffs and taxes, while export taxes were eliminated except on peanuts and phosphates. By 1984, after progress to stabilize the economy was deemed satisfactory, a new agricultural policy (NPA) 
was launched to organize the withdrawal of the state from the agricultural sector. By 1986, it was the transformation sector's turn, with a new industrial policy (NPI) aiming to dismantle tariff barriers. Another major decision was taken in 1986 to abandon administrative pricing (used to address undervaluation of declared imports) to calculate tariffs on imports.

The NPI action plan was comprised of four axes: revised protections for domestic industrial sectors, export promotion, revival of investments and improvement of the environment for industrial activities. According to the first, the tariff code was revised, with rates cut from 65 per cent to 30-40 per cent over two years and by reducing the number and range of applicable rates. The resulting reduction in the anti-export bias was supplemented by introducing an export subsidy which totalled 10 per cent of the FOB value of exports over 1980-83. This rose to 15 per cent of the FOB value over 1984-86 and 25 per cent of value added in export activities after 1986. Peanut products and phosphate exports, which did not benefit from the subsidy, saw tax levies eliminated in 1980. Reform of the export subsidy system was supplemented by establishing integrated credit insurance and financing system for the export of manufactured goods.

According to the third and fourth axes of the NPI action plan, the investment code was also revised, an industrial restructuring fund was created, and assistance and advice provided to investors was expanded. To improve the business environment in the industrial sector, measures aimed to liberalize prices and marketing channels, reduce production factor prices and simplify administrative formalities. However, these measures were adopted in a context of persistent domestic currency appreciation and declining competitiveness of Senegalese firms. In 1989, being pressured by firms and faced with declining tax receipts, the state had to postpone implementation of the second phase of the NPI, referred to as the recovery phase, committed to in 1988. The 1989 reform plan could not be implemented until 1994, as part of the overall adjustment initiated by devaluation of the CFA franc.

The NPI remains a painful failure in the history of economic reform in Senegal, with the closure of under- or uncompetitive firms causing significant job losses (7 per cent of permanent staff between mid-1987 and mid-1988).

\section{Implementation of a common external tariff}

The period preceding the 1994 devaluation saw a rich debate on the future of the West African Economic and Monetary Union (WAEMU). The perspective which prevailed was preservation of the Union, and ultimately provided the inspiration to transform it into an economic union with the goal of accelerating integration and convergence among economies in the CFA franc zone. This having been done, the goal of not creating a WAEMU 'fortress' was upheld and the union proceeded with tariff reductions and established a common external tariff (CET). The 50 per cent reduction in the FCFA exchange rate had already made possible the substantial 1994 reduction in tariff rates and simplification of import taxes which remained up to the initiative of each state.

The achievement of a customs union became reality through the movement of raw materials and of goods from small-scale producers, free of any tariffs or taxes among WAEMU member states, in addition to the 1996-2000 implementation of the WAEMU CET with four categories of products : social goods, the import of which is only charged a 1 per cent statistical tax (RS) and a 1 per cent community solidarity levy (PCS); basic necessities, raw primary materials, equipment goods and other specific inputs levied with a 5 per cent customs tariff plus the RS and the PCS upon import; other inputs and intermediate products which are levied a 10 per cent tariff plus the RS and the PCS; finally, final consumption goods and other products not listed elsewhere which are levied at a 20 per cent tariff rate plus the RS and the PCS. Two exceptional taxes, which were temporary and digressive, are the digressive protection tax (TDP) and a special import tax (TCI) 
were introduced to compensate for major declines in tariff protections associated with the CET (in the case of the TDP) or with erratic variations in world prices (in the case of the TCI).

Implementation of the CET is considered as a productivity shock comparable to the NIP except that it came in the wake of the major productivity gains associated with devaluation of the CFA franc. Over 1995-2005, industrial activities grew by an annual average of 3.8 per cent (IMF 2012).

\section{Deepening economic liberalization and other measures to promote the private sector}

In the first two post-independence decades, price administration, the predominance of public and mixed enterprises and the prevalence of a restrictive regulatory environment all severely hindered the development of private enterprise with the exception of a certain number of privileged entrepreneurs in terms of regulations and other advantages. Given the benefits from devaluation, special conventions and protocols were renegotiated, in that many benefits were eliminated or reduced. Similarly, price control regimes were made more flexible and the privatization programme initiated during the 1980s was extended to sectors previously considered as strategic, such as infrastructure services and the financial sector with the disappearance of the first public banks and the 25 per cent limit on the state's share of bank capital (Ministère de l'Economie et des Finances 1988). Concerning the labour market, the reforms carried out over 1994-97 allowed firms to resort to economic layoffs and also reduced restrictions on fixed-term labour contracts. The dynamics of reform and consultation with employer organizations which accelerated following devaluation of the FCFA in 1994 led to the joint development of a private sector development strategy adopted upon agreement between parties in April 1999 regarding rationalization of the private sector support plan and improvement of the efficacy of state intervention.

Implementation of this strategy following the March 2000 transfer of power began with the creation in that year of the Investment Promotion and Major Projects Agency, and in 2001 of the Agency for the Development and Supervision of SMEs. This was followed by the 2002 transformation of the Senegalese Standards Institute into an association in order to encourage professionals to be more accountable in product quality certification, the 2003 creation of the Modernization Office and in 2005, creation of the Senegalese Export Creation Agency. Previously, the interest of the state in improving the quality of its intervention in the economy and services provided to firms led to the January 2005 launch of a process to prepare the accelerated growth strategy (SCA) by building upon the benefits linked to and orientations of the private sector development strategy (SDSP) adopted in 1999.

The SCA offers a common framework to establish a business environment with international standards which benefits all sectors including: transformation activities, the promotion of promising sectors such as horticulture, agro industry, aquaculture, telecommunications and tourism or the improvement of sectors such as fisheries and textiles through a competitiveness cluster approach. The SCA action plan also includes development of special economic zones and other dedicated sites such as incubators, community agriculture areas as well as industrial, tourism and others zones. The industrial redeployment strategy launched in July 2005 is perfectly consistent with the SCA by aiming to rebalance industrial sites to correct for regional disparities and to reorient the productive apparatus of the country towards sectors with higher value added.

However, real GDP growth slowed considerably over 2006-11; the economy has proven rather vulnerable to the exogenous shocks of the energy, food and financial crises of 2007 to 2009. The industrial activity growth rate fell to 3.2 per cent during this period (FMI 2012). 


\subsection{The industrial policy framework and emerging questions}

The industrial sector is entrusted to an administration department which is also responsible for trade, SMEs and the informal sector. The redeployment and the industrial zones are the key features of the industrial sector policy validated in 2005. The objectives are: a rebalancing of industrial facilities across the country, which continue to be concentrated in the Dakar region; reorientation of the productive base towards new promising sectors; and strengthening of managerial capacities required to promote highly productive competitive industries.

The industrial redeployment policy (PRI) is thus part of the orientations and objectives of the SCA which, in turn, is part of the action plan to reach the productivity and growth objectives of the national social and economic development strategy, which is Senegal's third generation poverty reduction strategy document. Thus, the PRI rests on the stability of the macroeconomic environment, the policy of external openness and regional integration, the option to establish a business environment with international standards and the development of economic zones (Loi d'Orientation n²008-03 du 08 janvier 2008 sur la Stratégie de Croissance Accélérée, article 2). The competitiveness cluster approach is emblematic of opportunities for innovation within the SCA as well as for collaboration between actors along the value chain, which should also allow the PRI to create the conditions for better positioning of Senegalese products in both domestic and targeted foreign markets. With a focus on the competitiveness of Senegalese firms in the context of globalization, it goes beyond import substitution and export promotion policies, to provide the 1995-2005 growth trend with greater sectoral and social bases, to diversify the sources of growth and to sustain this growth.

The observed advantages of an effective industrial redeployment policy are: (i) the presence of important measures to increase value added in industrial sectors; (ii) increased accountability in the private sector; (iii) the ongoing process to develop infrastructure; and (iv) access to foreign markets. Complicating factors include: (i) the strong concentration of industrial activity and population in Dakar, sources of aggregation effects and economies of scale which may render the redeployment less beneficial; (ii) the lack of synergies between the industrial sector and small-scale producers; (iii) backwardness in entrepreneurial spirit and technological innovation; and (iv) the cost of developing industrial sites.

With respect to these directions of industrial policy in Senegal, emerging issues involve: (i) the necessary restructuring of the productive apparatus and the basket of exported products in order to accelerate growth; (ii) the quality and maintenance of structural competitiveness factors such as infrastructure, notably including energy and human resources, including entrepreneurial spirit; (iii) the role of the undervaluation of the real exchange rate in the success of industrial redeployment and acceleration of growth.

Globally, high tariff barriers were introduced not long after the independence and there have been strong state interventions in goods and service markets as well as in the labour market in the 1960s and 1970s. The strong market distortions led to the 1979s economic policy reforms. In the context of stabilization and structural adjustment programmes supported by the International Monetary Fund and the World Bank, domestic markets for goods and services were substantially liberalized, regulations were eliminated and multiple public enterprises were privatized.

By 2002, the import tax was average 14 per cent, equivalent to the developing country average. Moreover, all quantitative restrictions were eliminated; there are no export or import monopolies nor export taxes. Since the devaluation in 1994, the Senegalese industrial sector had experienced significant growth in the post-devaluation period although it has been slowing down since 2006. Despite the observed improvements, the Senegalese manufacturing sector is still concentrated in 
chemical industries, construction materials and agro-food industries, with relatively weak improvements in productivity. Other sectors performing well include grains, wheat, wood, printing and mechanical industries.

\section{The structure of the industrial sector}

Over the period 1985-93, economic activity in real terms grew annually by 2.3 per cent, while population growth stood at 2.4 per cent, implying the stability of the GDP per head. These figures reflect the disappointing results of the first structural adjustment programme implemented in Senegal (PAMLT). One of the main reasons behind the poor performance of the PAMLT was the currency misalignment.

With the currency adjustment that occurred in 1994, the situation changed dramatically and GDP growth followed a more favourable trend in the subsequent years: 5.4 per cent in 1998 and 6.5 per cent in 1999. After 2000, the growth rate was still high, but remained relatively unstable: 2003 , 2004 and 2005 were marked by a strong GDP growth, while during the years 2002, 2006, 2008 and 2009 a decline in GDP growth occurred due to the influence of climate and energy shocks as well as to the financial crisis. As a consequence, the average growth rate of GDP has fallen during the last ten years below that of the population, making the fight against poverty more difficult.

A recent growth diagnostic conducted by the African Development Bank (AfDB, 2012) argues that the main engine of growth in the last two decades has been the 1994 devaluation. The growth pattern in Senegal, as compared to other similar but more successful African countries, is below the level that would correspond to a sustainable growth pattern. Moreover, being unstable and vulnerable to climate shocks, the Senegalese growth does not mirror the economic take-off that occurred in the most successful emerging countries, and does not allow achieving the required decrease in endemic poverty.

Despite a relatively early industrialization, Senegal is characterized by a poorly distributed industrial production. Industrial production is mainly concentrated in Dakar with nearly nine out of ten firms and three quarters of permanent jobs and revenue in 1995.

The industrial sector is very heterogeneous in terms of age and firm size. Besides a small number of large firms established before or during the first years of independence and controlled by foreign interests or by the state, there are countless micro-firms. While large-scale firms included only 10 per cent of active firms between 1992 and 1995, they represent almost three quarters of total investment, jobs and revenue. Small firms count for three-fifths of the total number of industrial firms, and less than one-tenth of jobs and revenue (Republic of Senegal/UNDP 1997).

The tertiary sector consistently represented more than half of GDP: 61 per cent during the period 2000-10, against 58 per cent in 1980-1984. The contribution of the secondary sector, which was estimated at 19.5 per cent between 1980 and 1984, reached 22.6 per cent during the period 200010. By contrast, the primary sector share declined from 22.4 per cent to 16.8 per cent during the same periods. 
Figure 1: The evolution of the shares of the main sectors in industrial value added between 1980 and 2010

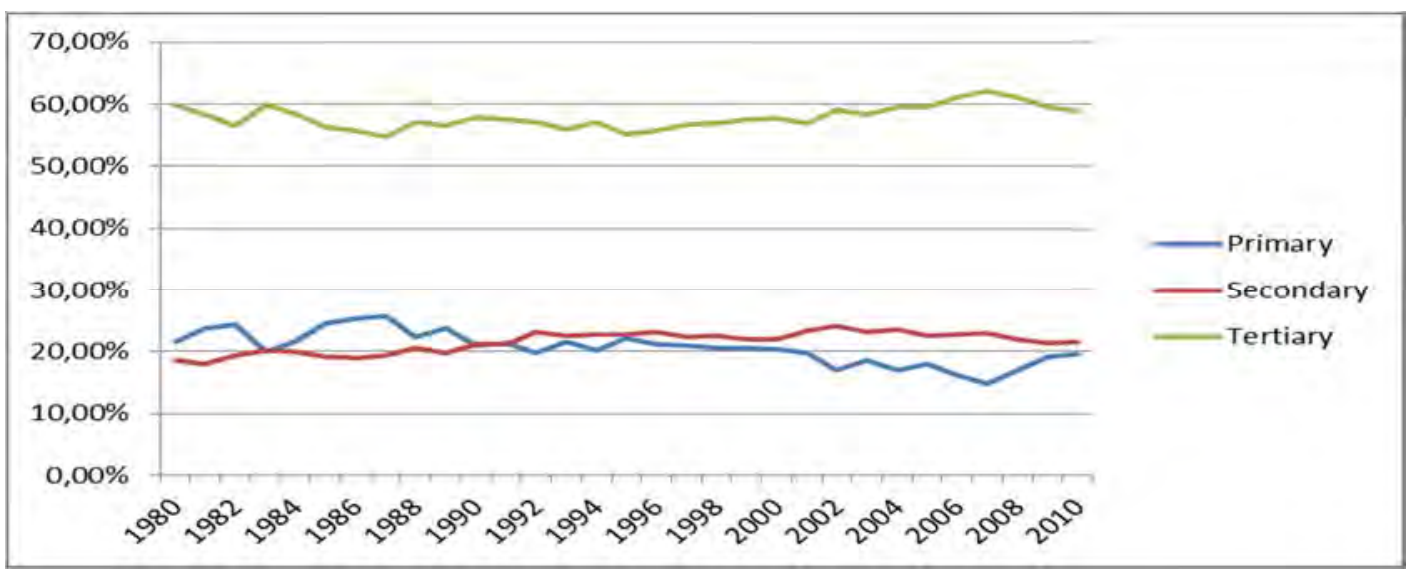

Source: ANSD (various years).

The main driver of growth is the tertiary sector, whose contribution to GDP growth was of 2.3 per cent after the devaluation and up to 2000 and at 2.8 per cent during the last decade. The two other sectors account for half of the GDP growth.

Furthermore, the industry contributes to 30 per cent of the value added of Senegalese enterprises. Its share in the total value added registered a decrease between 1999 and 2010 from 46.4 per cent at the beginning of the period to 28.35 per cent in 2010. However, in 2011 its value registered a slight increase to 30 per cent. On the contrary, the share of trade and services increased from 44.8 per cent to 63.54 per cent over the same period. In 2011 its value stood at 62.2 per cent.

At the level of the industrial sectors the main drivers are the electricity and water sector, the building sector, which accounted for 24.8 per cent and respectively 22.4 per cent in 2011 . They are followed by the chemical industry which accounts for 10.38 per cent and by the glass and pottery manufacturing industry accounting for 8.16 per cent of the industrial value added. These four sectors account for more than 65 per cent of the total industrial value added.

However, at the beginning of the 1990s things were different, while the first three sectors were still dominating with 26 per cent, 15 per cent and almost 10 per cent, respectively and almost 10 per cent of the industrial value added, the contribution of glass and pottery was less important. On the other hand, manufacturing and processing of sugar accounted for 8.27 per cent of the value added. In all, the first four sectors accounted for less than 60 per cent of the industrial value added.

The 1980s showed an even more different picture, with a more important part played by the electricity and water sector which contributed to 30 per cent of the industrial value added, while the chemical industry represented only 7 per cent of the total industrial value added. The building sector came third with a contribution of 12 per cent, while manufacturing and processing of sugar accounted for 13.8 per cent. Another important sector at the beginning of the 1980s whose importance has diminished since then was meat processing and preserving. This sector accounted for 7.5 per cent of the total industrial value added. The first four sectors accounted for 63.7 per cent of the total industrial value added.

One can conclude that over the last 30 years the production structure of the industrial sector in Senegal has remained concentrated at the level of a few sectors. Senegal's industrial production is very poorly diversified. While the share of some sectors has diminished in the total industrial value added, as it is the case of the manufacturing and processing of sugar and of the processing and 
preservation of meat, others (like the chemical industry and glass and pottery) have grown in importance.

Figure 2: Value added of Senegalese enterprises by economic sector, 1999-2011

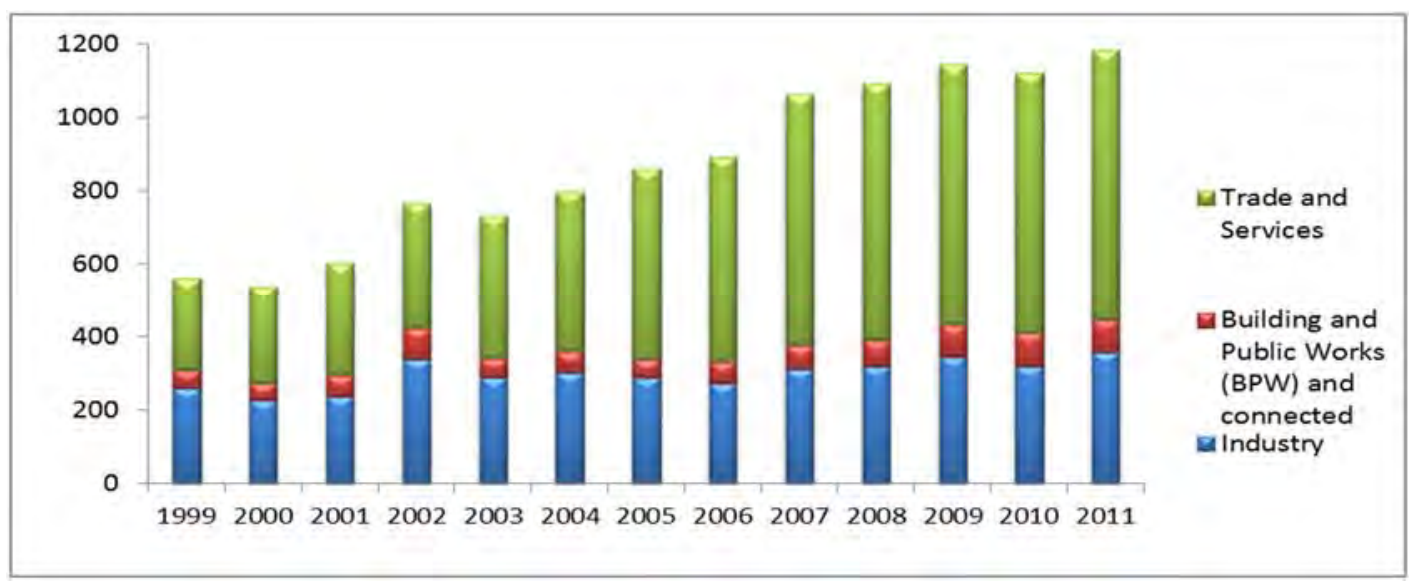

Source: ANSD (various years).

Table 1: The share of the industrial sectors in total industrial value added on a 5-years basis from 1980 to 2010

\begin{tabular}{|c|c|c|c|c|c|c|}
\hline Industrial sectors & $1980-85$ & 1986-93 & 1994-99 & $2000-04$ & $2005-10$ & $1980-2010$ \\
\hline Processing and preservation of meat and fish & 7.29 & 8.31 & 7.47 & 4.79 & 2.59 & 6.27 \\
\hline Edible fats & 2.87 & 1.90 & 2.60 & -0.21 & 0.56 & 1.62 \\
\hline Grain milling and manufacture of grain products & 1.91 & 2.80 & 2.73 & 1.32 & 1.57 & 2.14 \\
\hline Manufacturing of cereal foods & 0.35 & 0.47 & 0.51 & 0.28 & 0.34 & 0.40 \\
\hline Manufacturing and processing of sugar & 12.51 & 8.18 & 5.52 & 4.92 & 3.88 & 7.15 \\
\hline Manufacturing of other foods & 0.99 & 1.80 & 2.19 & 1.44 & 1.71 & 1.64 \\
\hline Manufacturing of beverages & 2.23 & 1.99 & 2.16 & 2.01 & 3.81 & 2.43 \\
\hline Manufacturing of tobacco products & 1.34 & 1.19 & 1.29 & 1.62 & 1.35 & 1.34 \\
\hline Cotton and textiles manufacturing & 3.52 & 3.29 & 3.28 & 2.32 & 1.45 & 2.82 \\
\hline Leather processing and manufacturing & 0.20 & 0.23 & 0.27 & 0.28 & 0.12 & 0.22 \\
\hline Woodworking/ manufacturing of wooden products & 0.38 & 0.53 & 0.62 & 0.34 & 0.06 & 0.40 \\
\hline Paper and stationery & 3.33 & 3.92 & 4.20 & 4.82 & 5.82 & 4.37 \\
\hline Petroleum processing and coking & 0.28 & 0.22 & 1.21 & 3.21 & 2.66 & 1.38 \\
\hline Chemical industry & 7.24 & 8.79 & 13.99 & 14.75 & 11.09 & 10.90 \\
\hline Production of rubber products & 2.70 & 2.73 & 2.44 & 3.54 & 3.55 & 2.96 \\
\hline Glassware and pottery manufacturing & 4.10 & 3.41 & 3.95 & 6.21 & 9.10 & 5.20 \\
\hline Metallurgy, foundry and foundry services & 3.66 & 4.07 & 4.57 & 4.81 & 5.22 & 4.43 \\
\hline Manufacturing of machines & 0.48 & 0.56 & 0.64 & 0.88 & 0.81 & 0.66 \\
\hline Manufacturing of equipment/ devices (appliances) & 0.00 & 0.00 & 0.00 & 0.00 & 0.00 & 0.00 \\
\hline Manufacturing of transportation equipment & 0.33 & 0.41 & 0.30 & 0.32 & 0.50 & 0.38 \\
\hline Manufacturing of various products & 1.72 & 1.70 & 1.58 & 1.40 & 1.07 & 1.51 \\
\hline Electricity, water and gas & 29.30 & 26.86 & 20.34 & 19.12 & 22.09 & 23.90 \\
\hline Building industry & 13.27 & 16.64 & 18.15 & 21.84 & 20.62 & 17.89 \\
\hline Total & 100.00 & 100.00 & 100.00 & 100.00 & 100.00 & 100.00 \\
\hline
\end{tabular}

Source: ANSD (various years).

As shown in Table 1, during the last 30 years the main sectors triggering the Senegalese industrial value added were the electricity and water, the building sector, the chemical industry and the manufacturing and processing of sugar, each accounting for 23.9 per cent, 17.89 per cent, 10.9 per 
cent and 7.15 per cent of the industrial value added of the period. At the beginning of the 1980s the dominating sectors were energy, the building industry, manufacturing and processing of sugar as well as processing and preservation of meat and fish. During the five years between 2005 and 2010, there were some important changes: while the energy and the building industries are still the first sectors in terms of value added, the energy sector has significantly lost in importance (7 percentage points). They are followed by the chemical sector and the paper and stationery sector.

Over the last five years, the sectors that recorded the most important growth rates were the edible fats industry, the manufacturing of beverages, followed by the manufacturing of transportation equipment and the manufacturing of cereal food products. However, their contribution to the total value added is very low, no more than 5 per cent in all. At the same time, the sectors whose share in total industrial value added diminished the most over the period 2005 to 2010 are the woodworking and the manufacture of wooden products, the leather processing and manufacturing and the cotton and textiles industry. Each of them accounts for 0.06 per cent, 0.12 per cent and 1.45 per cent of the total value added over the period.

Figure 3: Structure of the value added by industrial sector over the last 30 years, $1980-2000$

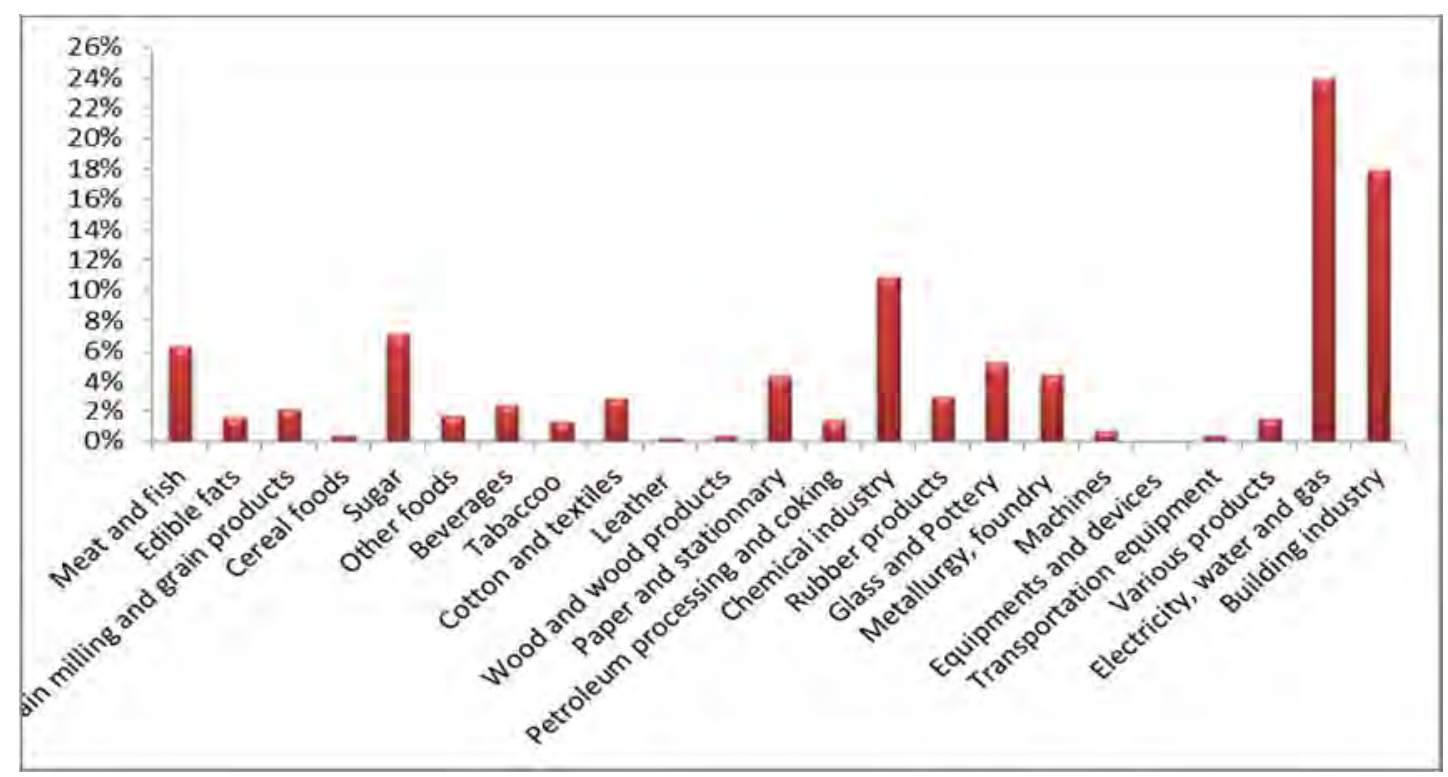

Source: ANSD (various years).

Table 2: The share of the modern industrial sector and of the informal sector in the total industrial value added on a 5-year basis, 1980-2010

\begin{tabular}{lccc}
\hline Period & Modern & Informal & Total \\
\hline $1980-85$ & 44.79 & 55.21 & 100.00 \\
$1986-93$ & 44.28 & 55.72 & 100.00 \\
$1994-99$ & 44.22 & 55.78 & 100.00 \\
$2000-04$ & 44.45 & 55.55 & 100.00 \\
$2005-10$ & 46.22 & 53.78 & 100.00 \\
\hline $1980-2010$ & 44.77 & 55.23 & 100.00 \\
\hline
\end{tabular}

Source: ANSD (various years). 
The share of the formal modern industrial sector in total industrial value added has diminished from 47.4 per cent at the beginning of the 1980s to 45.9 per cent in 2010. Overall, its evolution over the last thirty years was smooth. The lowest value of 42.3 per cent at the middle of the 1980s and again at the beginning of the new millennium, while the highest value of over 47 per cent attained at the beginning of the 1980s and again in 2007.

Table 2 shows the contribution of the formal modern sector to the industrial value added over five-year periods starting from the 1980s until 2010. In the last five years, the share of the formal modern industrial sector stood at around 46 per cent, higher than during the preceding periods.

\subsection{Employment}

At the beginning of the 1980s the most important part of the active labour force was employed in the manufacturing and processing of sugar (19 per cent), in the production of rubber products (about 10 per cent), in the electricity, water and gas production sector and in the manufacturing of machines (about 8.5 per cent each). In 2010 the distribution of the labour force among the industrial sectors was quite different. Over a third of the active labour force worked in the building sector (almost 36 per cent), while 10 per cent worked in the electricity, water and gas production sector. The following two sectors, processing and preservation of meat and fish and manufacturing and processing of sugar, employed together about 15 per cent of the active labour force.

Table 3: Employment rates by sectors on a 5-year basis, 1980-2010

\begin{tabular}{|c|c|c|c|c|c|c|}
\hline Sectors & $1980-85$ & 1986-93 & 1994-99 & $2000-04$ & $2005-10$ & $1980-2010$ \\
\hline Processing and preservation of meat and fish & 7.96 & 6.95 & 8.06 & 6.75 & 7.32 & 7.40 \\
\hline Edible fats & 5.72 & 6.91 & 4.96 & 7.36 & 6.80 & 6.35 \\
\hline Grain milling and manufacture of grain products & 0.92 & 1.17 & 1.31 & 1.41 & 1.33 & 1.22 \\
\hline Manufacturing of cereal foods & 2.01 & 1.74 & 1.46 & 1.00 & 0.70 & 1.42 \\
\hline Manufacturing and processing of sugar & 18.85 & 17.34 & 11.80 & 11.84 & 8.69 & 14.00 \\
\hline Manufacturing of other foods & 1.42 & 2.59 & 2.95 & 3.59 & 4.74 & 3.01 \\
\hline Manufacturing of beverages & 0.93 & 1.23 & 1.15 & 1.19 & 1.64 & 1.23 \\
\hline Manufacturing of tobacco products & 1.32 & 1.08 & 0.66 & 0.50 & 0.42 & 0.82 \\
\hline Cotton and textiles manufacturing & 5.62 & 6.30 & 5.95 & 5.06 & 5.38 & 5.72 \\
\hline Leather processing and manufacturing & 0.11 & 0.20 & 0.44 & 0.60 & 0.90 & 0.43 \\
\hline Woodworking/ manufacturing of wooden products & 0.24 & 0.29 & 0.43 & 0.38 & 0.26 & 0.32 \\
\hline Paper and stationery & 5.24 & 5.05 & 4.32 & 3.45 & 2.65 & 4.22 \\
\hline Petroleum processing and coking & 3.38 & 2.00 & 1.19 & 1.34 & 0.31 & 1.68 \\
\hline Chemical industry & 8.02 & 8.73 & 7.92 & 7.33 & 6.81 & 7.84 \\
\hline Production of rubber products & 8.34 & 5.37 & 4.98 & 4.19 & 1.05 & 4.84 \\
\hline Glassware and Pottery manufacturing & 0.49 & 0.88 & 1.00 & 1.71 & 2.48 & 1.27 \\
\hline Metallurgy, foundry and foundry services & 4.45 & 3.37 & 5.43 & 4.22 & 1.04 & 3.66 \\
\hline Manufacturing of machines & 6.04 & 2.37 & 1.16 & 0.84 & 0.12 & 2.17 \\
\hline Manufacturing of equipment and devices & 0.00 & 0.00 & 0.00 & 0.03 & 0.15 & 0.04 \\
\hline Manufacturing of transportation equipment & 1.50 & 1.83 & 0.96 & 1.89 & 1.88 & 1.62 \\
\hline Manufacturing of various products & 1.01 & 1.45 & 1.48 & 1.97 & 2.34 & 1.63 \\
\hline Electricity, water and gas & 9.12 & 10.76 & 11.84 & 11.29 & 10.10 & 10.61 \\
\hline Building industry & 7.31 & 12.39 & 20.55 & 22.05 & 32.87 & 18.51 \\
\hline Total & 100.00 & 100.00 & 100.00 & 100.00 & 100.00 & 100.00 \\
\hline
\end{tabular}

Source: ANSD (various years). 
In spite of this state of affairs, the most significant increase in the number of employees over the last thirty years was recorded in the leather processing and manufacturing sector, followed by the glassware and pottery sector and the building sector. The fourth sector in terms of the number of employees was the manufacturing of other foods. These sectors have seen the most important growth rates in number of employees also during the last decade (between 2000 and 2010). However, except for the building sector, the contribution of the other sectors to the total industrial value added was quite low, amounting to 7 per cent for the three sectors over the thirty-year period. Of the three sectors the glassware and pottery producing sector was the most important, accounting for 5.2 per cent of the total industrial value added. These facts seem to indicate a low labour productivity in these sectors.

Figure 4: The structure of the labour force by industrial sector over the last thirty years, 1980-2000

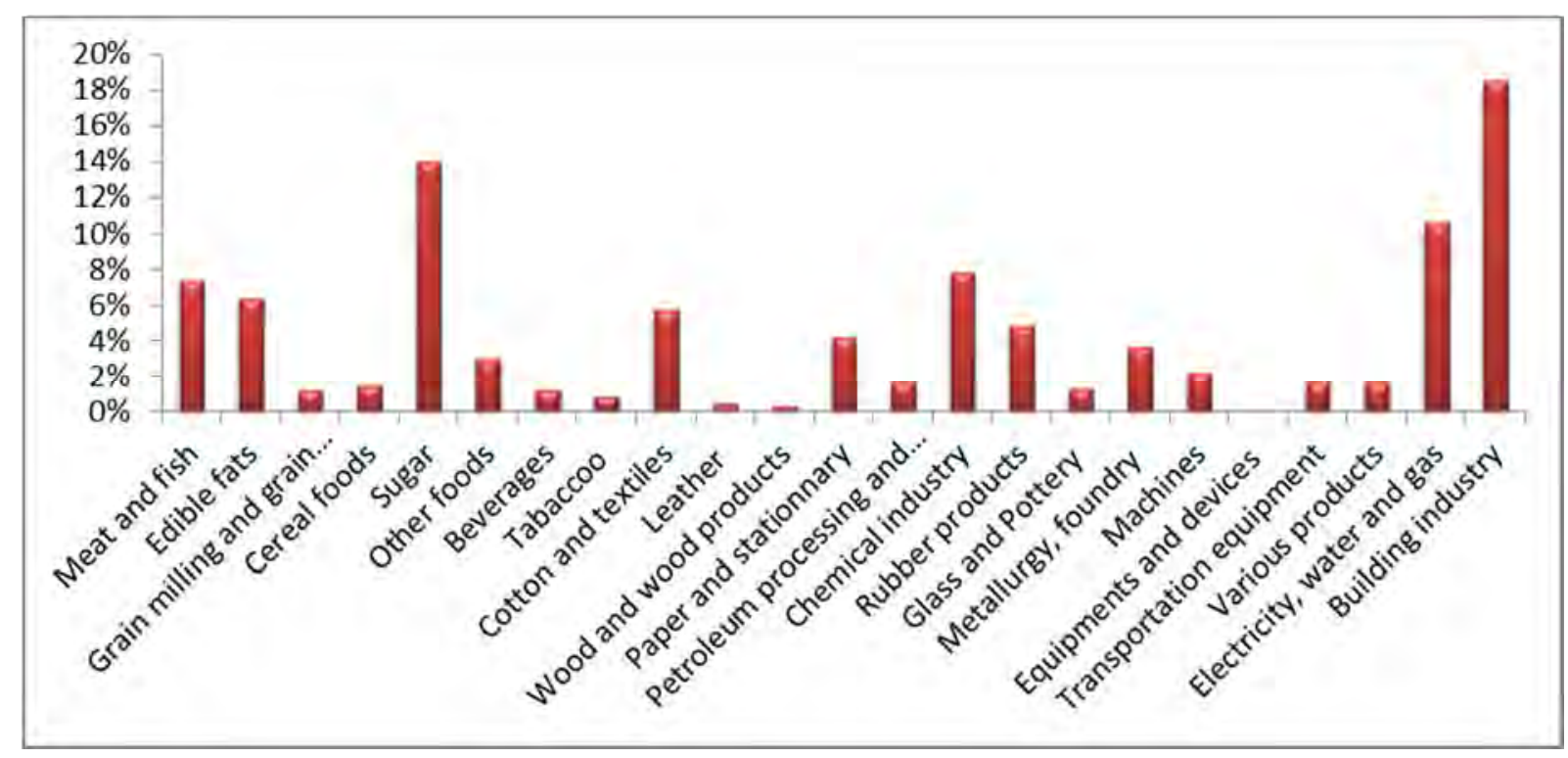

Source: ANSD (various years).

\subsection{Foreign direct investment}

Throughout Africa, FDI increased fivefold, reaching US $\$ 30$ billion, with a change in their geographical origin. At present FDI comes mainly from Asia, China and Singapore, followed by Europe. In the case of Senegal, FDI comes mainly from Europe, with France in a leading position.

FDI inflows to Senegal between 2000 and 2005 represented a mere 1 per cent of GDP and 2.5 per cent of GDP in 2006 and 2007, the average ratio of FDI to GDP for Africa was 3 per cent. The impact of the FDIs on growth varied greatly from country to country, because of the existence of technological spillovers contingent on the absorptive capacity of the recipient countries.

\subsection{Number of firms}

As of 2011, 19 per cent of the firms were concentrated in the building sector, almost 9 per cent in the plumbing and finishing sector and in the paper industry; 8 per cent in the chemical industry; 6.5 per cent in the pastry industry and 5.4 per cent in the processing of fruit and vegetables and other food sector as well as in the metallurgical sector and in the energy sector.

Between 1998 and 2011 the number of firms decreased by 50 per cent. The highest peak of the period was in 2006 with 594 firms. The evolution of the number of firms during the period is characterized by volatility with a lot of firms appearing and disappearing over the years. For 
example, in 2006 over 100 firms were set up, but in 2007 the number of closures was higher than the number of new entrants in the preceding year.

Table 4: Number of firms per industrial sectors

\begin{tabular}{|c|c|c|c|c|c|c|c|}
\hline Industrial sector & 1998 & 1999 & 2000 & 2001 & 2002 & 2003 & 2004 \\
\hline Building sector & 59 & 64 & 57 & 54 & 52 & 54 & 95 \\
\hline Plumbing & 40 & 46 & 38 & 35 & 37 & 36 & 46 \\
\hline Chemical industry & 33 & 32 & 29 & 30 & 34 & 31 & 39 \\
\hline Paper industry & 36 & 36 & 37 & 32 & 35 & 32 & 36 \\
\hline Pastry industry & 22 & 26 & 19 & 16 & 27 & 26 & 43 \\
\hline Energy & 7 & 7 & 6 & 7 & 8 & 9 & 10 \\
\hline Processing of fruit and vegetables and other foods & 17 & 16 & 20 & 19 & 18 & 19 & 23 \\
\hline Metallurgy & 19 & 19 & 19 & 17 & 18 & 23 & 28 \\
\hline Rubber industry & 19 & 21 & 23 & 22 & 23 & 18 & 19 \\
\hline Agriculture, breeding and chasing & 7 & 5 & 8 & 8 & 7 & 9 & 11 \\
\hline \multirow[t]{2}{*}{ Total } & 387 & 407 & 382 & 360 & 382 & 374 & 475 \\
\hline & 2005 & 2006 & 2007 & 2008 & 2009 & 2010 & 2011 \\
\hline Building sector & 103 & 149 & 109 & 122 & 126 & 82 & 49 \\
\hline Plumbing & 43 & 56 & 35 & 40 & 40 & 29 & 23 \\
\hline Chemical industry & 39 & 40 & 35 & 32 & 27 & 28 & 21 \\
\hline Paper industry & 37 & 40 & 32 & 33 & 30 & 25 & 20 \\
\hline Pastry industry & 42 & 57 & 43 & 58 & 58 & 43 & 17 \\
\hline Energy & 12 & 14 & 12 & 15 & 18 & 14 & 14 \\
\hline Processing of fruit and vegetables and other foods & 23 & 25 & 25 & 25 & 19 & 23 & 14 \\
\hline Metallurgy & 25 & 34 & 20 & 26 & 17 & 15 & 14 \\
\hline Rubber industry & 17 & 18 & 18 & 17 & 18 & 17 & 12 \\
\hline Agriculture, breeding and chasing & 8 & 15 & 15 & 19 & 21 & 16 & 10 \\
\hline Total & 480 & 594 & 469 & 511 & 480 & 370 & 261 \\
\hline
\end{tabular}

Source: AfDB (2012).

\subsection{Exports}

In the following section we present an estimation of the Imbs and Wacziarg (2003) equation. This equation consists of a non-linear model that links diversification indicators like the Herfindahl index and the level of development as measured by GDP per capita. We believe this model to be valid in the African context. According to this model, poor countries tend to diversify and only after reaching a certain income threshold, does specialization once again dominate the development process.

The estimation proposed below (AfDB 2012) covers a sample of 53 African countries between 1980 and 2010. The dependant variable is the Herfindhal index which varies between 0 and 1; lower values indicate greater diversification of exports. Goods but not services are factored in. GDPs vary in a sufficiently wide range to allow estimation of the Imbs and Wacziarg (2003) model.

The negative (positive) sign of GDP per capita (GDP per capita squared) indicates that the Herfindahl initially falls to a critical threshold of GDP per capita of US\$6313 (constant 2005 US dollars) and increases from that threshold. The computations give a result very similar to that of Imbs and Wacziarg (2003: 74), where the threshold is estimated at US\$9000 (constant 1985 dollars), i.e., US $\$ 10500$ at constant 2000 dollars. 
Table 5: Estimation: U-shaped pattern between diversification of exports and GDP

\begin{tabular}{lcc}
\hline Herfindhal index & Estimated coefficient & T-Statistics \\
\hline GDP per capita & -0.0000173 & -1.89 \\
Squared GDP per capita & $1.37(\mathrm{e}-09)$ & 3.54 \\
Population & $-1.19(\mathrm{e}-09)$ & -1.58 \\
Constant & 0.3898 & 11.19 \\
Number of observations & 1171 & \\
\hline
\end{tabular}

Source: See text.

Furthermore, Imbs and Wacziarg (2003) compute a theoretical or potential specialization indicator as well as the effective specialization to potential ratio. It stood at about 20 per cent between 2000 and 2006 (dates for which data are available), which means that Senegal is above its natural diversification potential, and not much can be expected of a proactive policy.

Figure 5 illustrates the non-linearity between growth and specialization in an African country context: first there is an increase in diversification, parallel to the development process, then a specialization process for the most advanced countries in the development process. Whereas Botswana, Mauritius, the Seychelles, South Africa and Tunisia are beyond the critical threshold, Senegal with a GDP per capita in 2010 of US\$1700 (in constant 2000 US dollars) is below the threshold from which growth leads to specialization. It is situated in the area where growth leads to continuing diversification.

Figure 5: Herfindahl index and GDP per capita

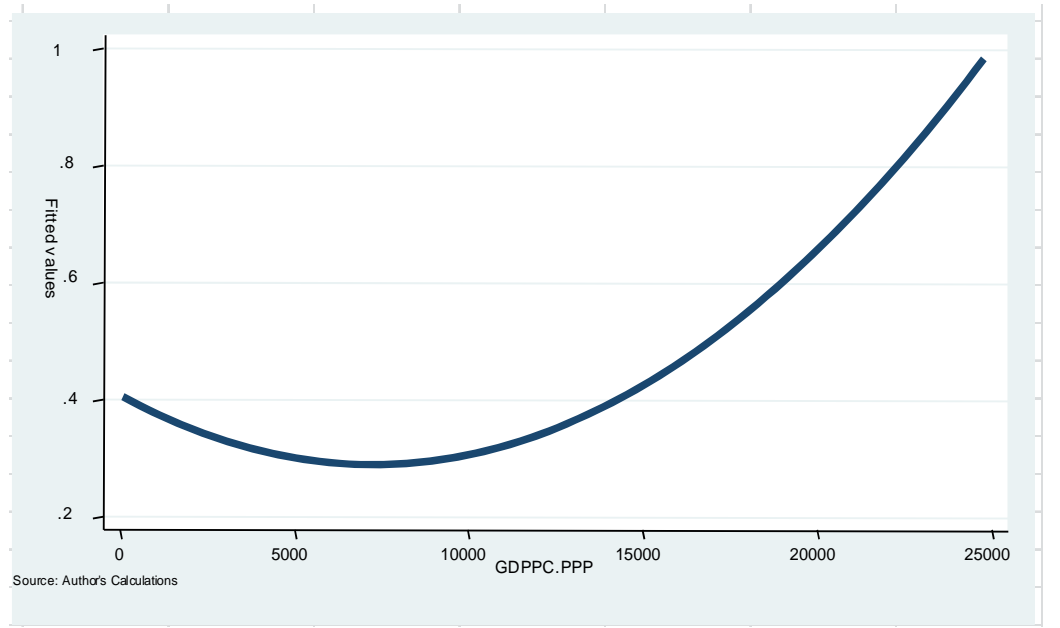

Source: AfDB (2012).

The trend of the indicator in Figure 6 shows a slight fall, that is, increased export diversification. There was in fact an 80 per cent drop for the first ten products in 2004 and 60 per cent in 2010. The figure shows that there was not a real diversification trend over the period 1980 to 2010 and that exports remain highly concentrated.

At the level of international trade, the most important share in Senegalese exports in 2011 was in the chemical industry (23.55 per cent). This was followed by petroleum processing and coking which accounted for almost 20 per cent of the exports. The third most important exporting sector was glassware and pottery manufacturing accounting for about 11 per cent of the Senegalese exports. These three sectors together represented over half of the Senegalese exports. At the same time, the food producing sectors (processing and preservation of meat and fish, edible fats, 
manufacturing of other foods) accounted for 20 per cent of the exports, while manufacturing of tobacco products accounted for over 5 per cent of the rest.

Figure 6: Trend of Herfindhal index in Senegal

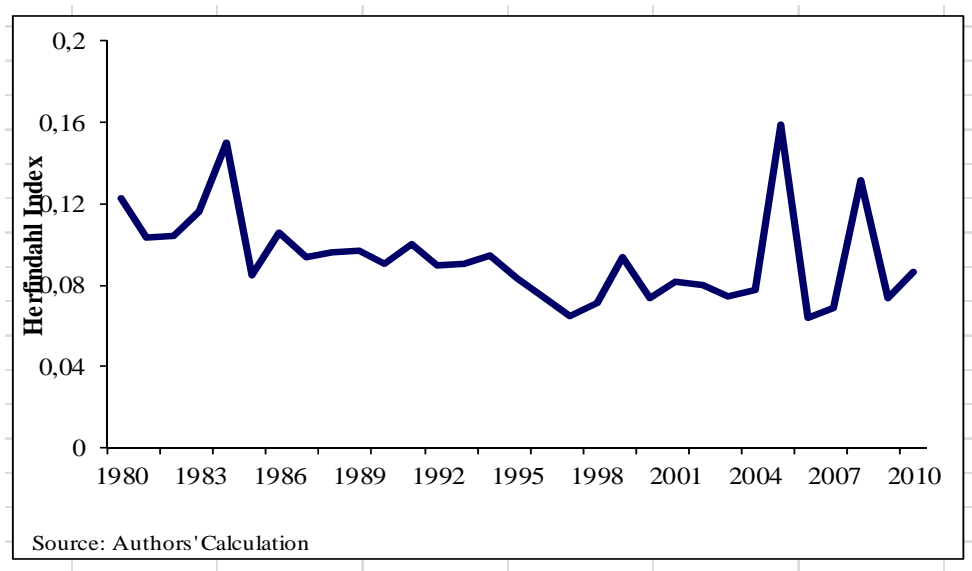

Source: Authors' calculations based on AfDB (2012).

The results are corroborated by the analysis of the exports sophistication indicator. The weighted revenue value of the basket of Senegalese exports rises slightly although still remaining slightly below US\$6000 over the entire period.

Figure 7: Exports sophistication index for Senegal

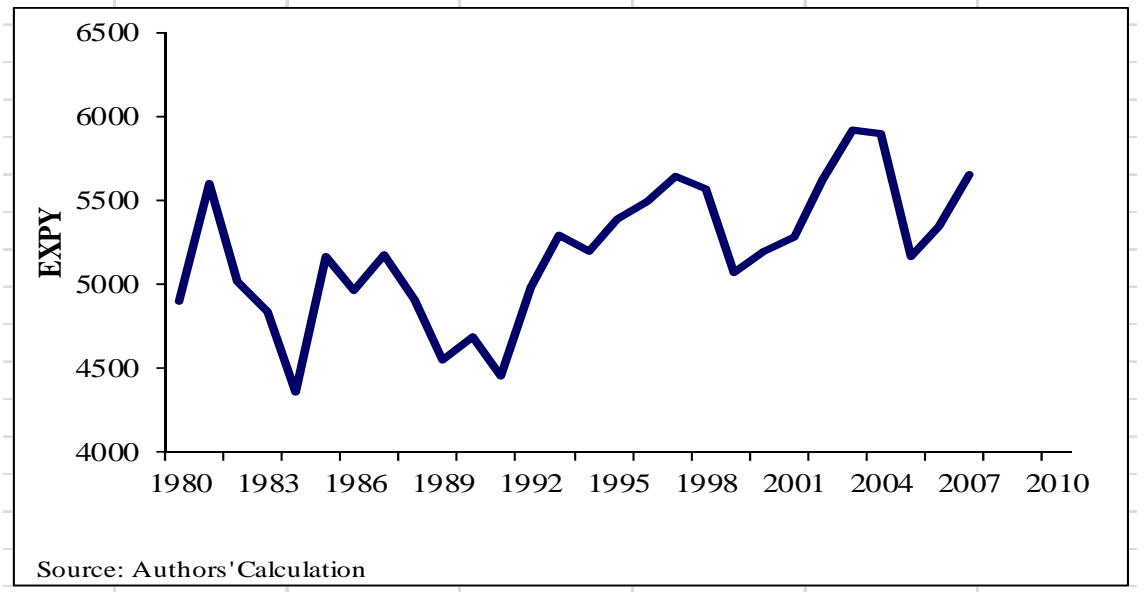

Source: Authors' calculations based on AfDB (2012).

These results indicate that Senegal undoubtedly has a much greater problem with the sophistication of its output than with its diversification. However, the main exporting industries have seen many fluctuations in the last 13 years, with the share of the processing and preservation of meat and fish diminishing from 34 per cent in 1997 to only 9.85 per cent in 2011. The sector's lowest share of Senegalese exports, less than 8 per cent, was recorded in 2008. At the same time, the share of the main exporting sector, the chemical industry, was bigger at the beginning of the period (over 33 per cent in 1998), dipping to its lowest level (14 per cent) in 2006. Petroleum processing and coking (at 47 per cent) attained the highest level of exports in 2000, before dropping and then growing again. The most impressive evolution over the period was registered by the glassware and pottery industry, which accounted for only 0.5 per cent of exports in 1997, achieving almost 12 per cent in 2010. But the conclusion is that Senegalese exports are unstable and volatile. They are also poorly diversified with three sectors accounting for more than 55 per cent of exports and other 
three for more than a quarter of the remaining Senegalese exports. Figure 9 shows the evolution of the main exporting sectors between 1997 and 2011.

Figure 8: The fluctuating shares of the main exporting sectors, 1997 and 2011

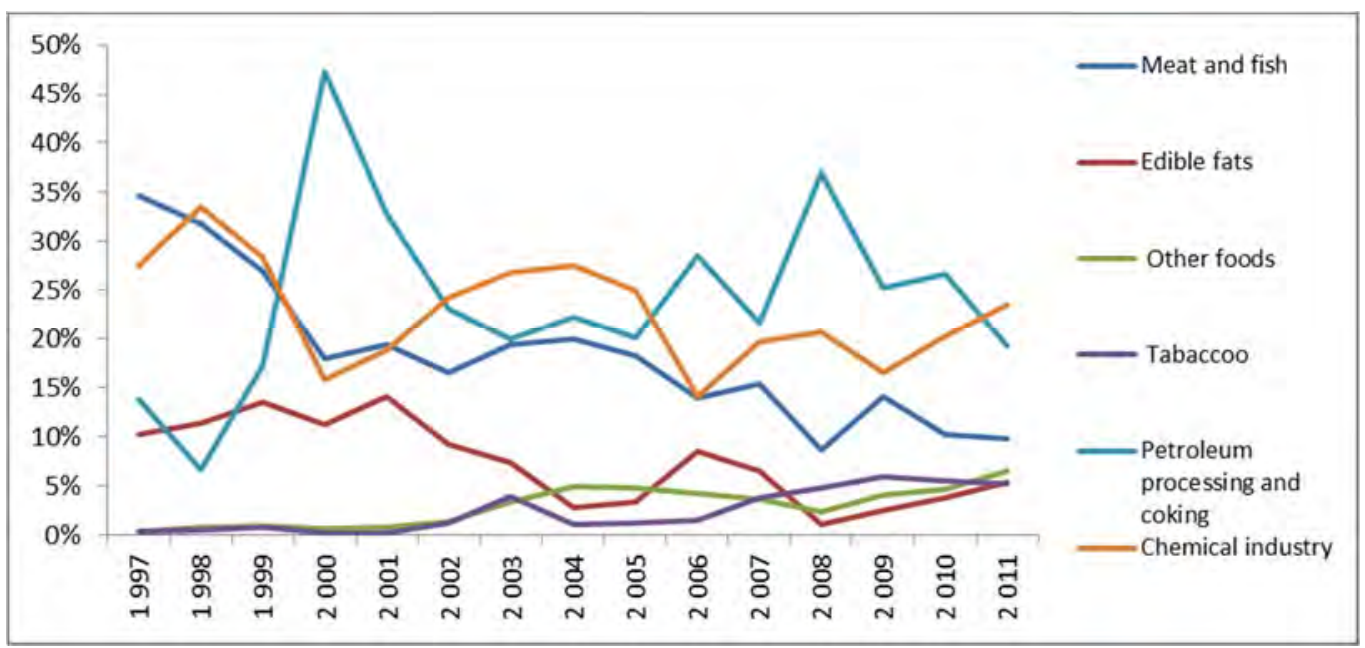

Source: AfDB (2012).

At the same time, other countries, which in 1980 had the same GDP per capita as Senegal show mixed EXPY indicators. Export sophistication improves more in countries with stronger growth rates such as Cape Verde, Sri Lanka and Indonesia (or even Malaysia, Tunisia, South Africa). It stagnates at a relatively low level in countries with the same growth profile as well as in countries with the poorest performances (Figure 9).

Figure 9: Exports sophistication index in African countries between 1980 and 2006
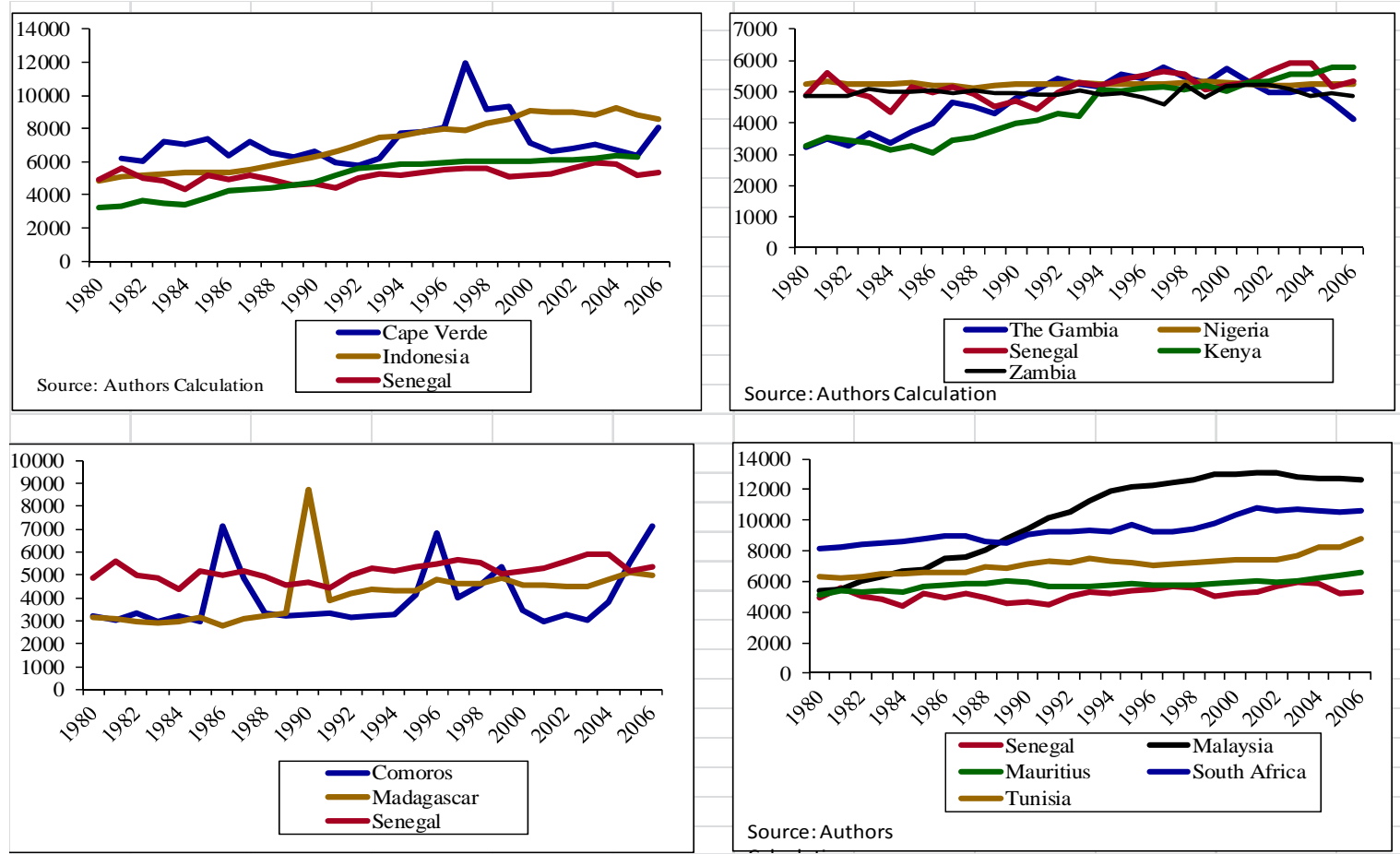

Source: AfDB (2012).

We can conclude that the main sunrise industries that we are able identify at the level of the Senegalese economy are the building industry, the chemical industry, the glassware and pottery 
industry while we would classify the processing and preservation of meat and fish and other food industries among the sunset sectors.

\section{$4 \quad$ Patterns of industrial productivity}

A simple way to assess the return on investment is to analyse the total factor productivity (TFP). We report in Figure 10 the level of aggregate TFP, which is borrowed from the ADB 2012 report. The level of TFP is low. It decreased steadily until 1994 then rose slightly until 2006, the year which marked the beginning of the crisis. The TFP growth rate does not reflect any stable improvement. On the contrary, it is very uneven, a characteristic that could be explained by the fluctuations in rainfall.

TFP is estimated in an accounting manner on the basis of a Cobb-Douglas function with constant returns to scale, assuming income to capital elasticity of 0.35 (i.e., a value close to 0.3 and 0.4 , which are the two values retained by Berthélémy et al. (1996: 49).

The contribution of each factor to growth is computed on the basis of the average growth rates of labour and capital. Thus, over the 1995-2004 decade, 38 per cent of Senegalese growth was due to the accumulation of physical capital, 43 per cent to labour and 16 per cent to an improvement in TFP. Between 1995 and 2009, these figures were respectively 49 per cent, 47 per cent and only 3 per cent for TFP. Therefore, we can conclude that the Senegalese growth model is evolving towards a change in the respective weights of labour and capital in growth, with a significantly more important role played by capital than in the previous period (1960 to 1990). By applying the same methodology, Berthélémy et al. in 1996 found the following percentages: 22 per cent attributable to capital, 58 per cent to labour, and 20 per cent to TFP. The TFP contribution to growth remains therefore stable and small.

Figure 10: Total factor productivity (TFP) in terms of levels and variations
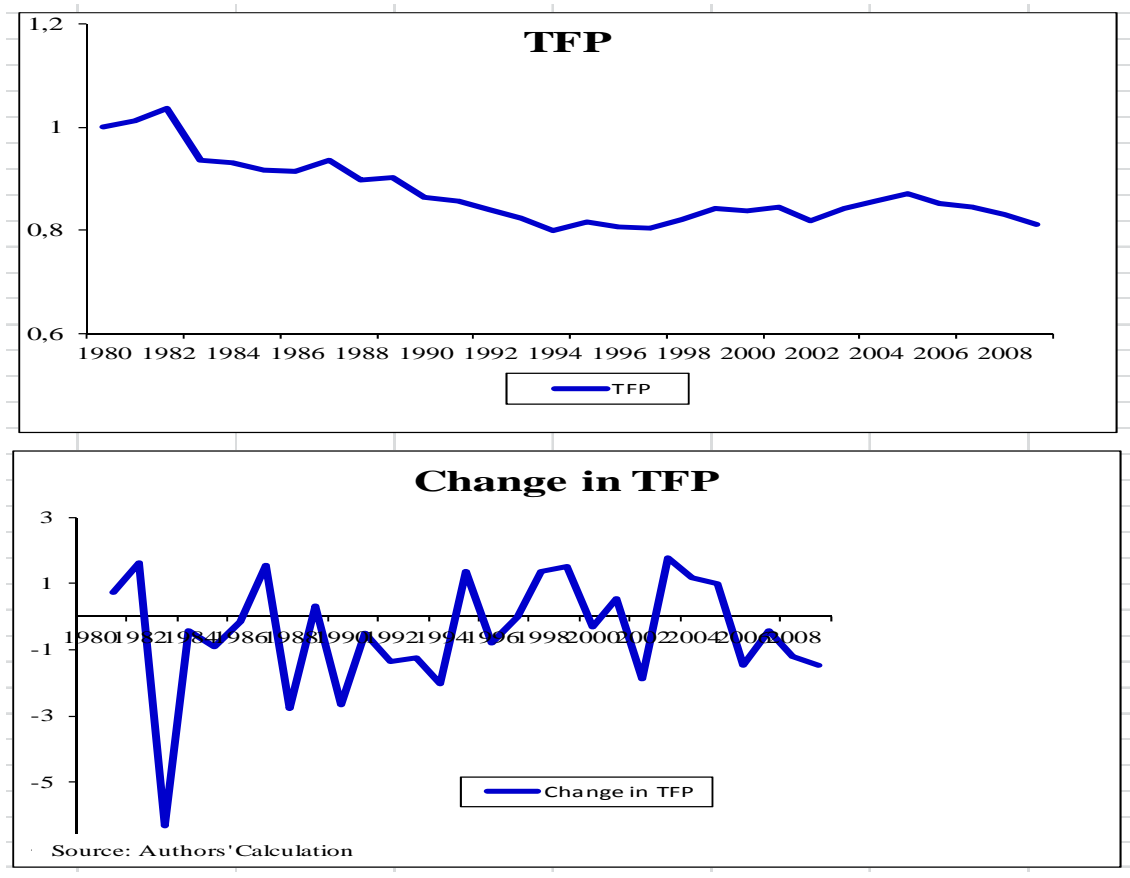

Source: Authors' calculations based on AfDB (2012). 


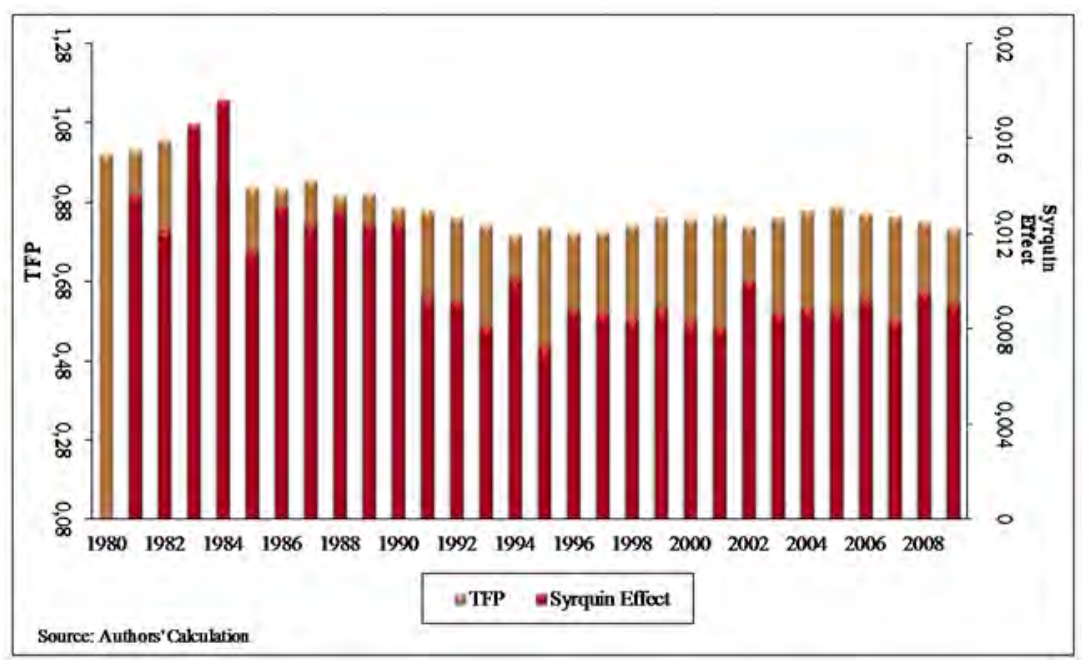

Note: The effect of the impact of labour mobility is estimated as the sum of the growth rates of the sectoral share of total employment weighted by the sectoral share of total value-added. The contribution of labour is calculated by multiplying the Syrquin effect by the output elasticity of labour, i.e. 0.65.

Source: Authors' calculations based on AfDB (2012).

The computation of the Syrquin effect suggests that 16 per cent of growth due to improved TFP mainly stems from the reallocation of labour from the agricultural sector to the secondary and tertiary sectors, characterized by higher labour productivity (Figure 8). The slow progress of TFP can be only partially attributed to technical progress or to the streamlining of production. These patterns stem from a simple mechanical impact of the migration of labour, which leads to the conclusion that the Senegalese growth model still remains highly fragile.

Next we exploit the database coming from annual surveys conducted by the CUCI (Centre Unique de Collecte de l'Information) of the National Agency of Statistics and Demography of Senegal. The surveys record information needed for the calculus and collection of taxes. Registration is mandatory for firms in the formal sector, with sales above 50 million FCFA. However, firms can choose to pay a flat tax in which they are not required to fulfil and return the CUCI questionnaire. Thus, distortions exist in the CUCI database, as it does not contain information on all manufacturing sector companies. The major firms in Senegal are registered.

Currently the database collates information on about 1,599 firms in the Senegalese manufacturing industry between 1997 and 2010, including sales, output, value added, revenues of capital, staff, consumption of intermediate inputs, identification of the sector in which the firm operates and a classification code that distinguishes the large, medium and small businesses. This size categorization, however, may change over time, and a firm listed as small in a given year may change its status in subsequent years. The data cover all the major two-digit manufacturing industries according to the International Standard Industrial Classification.

Maurel and Seghir (2014) estimate a Cobb Douglass production function. Imposing constant returns to scale, the estimated elasticity of output with respect to capital is statistically significant and ranging at 0.46 .

The sectors with the highest TFP in 2011 were manufacturing of other foods; manufacturing of various products; manufacturing and processing of sugar, as well as metallurgy, foundry and foundry services. It is interesting to notice that the most dynamic sectors do not play an important part either in terms of the number of employees or in terms of value added. At the beginning of 
the period, in 1998, the highest TFP was recorded in the subsectors pertaining to manufacturing of other foods; manufacturing of various products, production of rubber products and processing and preservation of meat and fish.

Table 6: TFP rates by industrial sector

\begin{tabular}{|c|c|c|c|c|c|}
\hline & 1998 & 2000 & 2007 & 2011 & $1998-2011$ \\
\hline Processing and preservation of meat and fish & 15.96 & 14.94 & 14.81 & 14.86 & 15.17 \\
\hline Edible fats & 14.55 & 14.45 & 14.27 & 14.14 & 14.26 \\
\hline Grain milling and manufacture of grain products & 15.21 & 15.17 & 14.98 & 15.04 & 15.07 \\
\hline Manufacturing of cereal foods & 15.19 & 15.38 & 15.32 & 14.84 & 15.27 \\
\hline Manufacturing and processing of sugar & 15.51 & 15.20 & 15.24 & 15.71 & 15.33 \\
\hline Manufacturing of other foods & 17.11 & 16.50 & 16.85 & 16.84 & 16.84 \\
\hline Manufacturing of beverages & 14.00 & 14.02 & 13.98 & 13.93 & 14.00 \\
\hline Manufacturing of tobacco products & 14.07 & 14.35 & 14.74 & 14.73 & 14.58 \\
\hline Cotton and textiles manufacturing & 15.88 & 15.73 & 15.31 & 15.40 & 15.51 \\
\hline Leather processing and manufacturing & 14.95 & 14.95 & 14.95 & 15.02 & 14.93 \\
\hline Wood working/manufacturing of wooden products & 14.55 & 14.69 & 14.53 & 14.34 & 14.57 \\
\hline Paper and stationery & 14.56 & 14.47 & 14.47 & 14.56 & 14.49 \\
\hline Petroleum processing and coking & 13.53 & 14.13 & 14.19 & 14.70 & 14.28 \\
\hline Chemical industry & 14.51 & 14.44 & 14.07 & 14.35 & 14.25 \\
\hline Production of rubber products & 16.49 & 16.55 & 16.17 & 15.68 & 16.12 \\
\hline Glassware and Pottery manufacturing & 14.93 & 14.89 & 14.85 & 14.78 & 14.83 \\
\hline Metallurgy, foundry and foundry services & 15.44 & 15.44 & 15.78 & 15.69 & 15.79 \\
\hline Manufacturing of machines & 14.87 & 14.74 & 14.38 & 14.30 & 14.54 \\
\hline Manufacturing of equipment and devices (appliances) & 14.30 & 14.64 & 14.47 & 14.58 & 14.49 \\
\hline Manufacturing of transportation equipment & 14.20 & 14.47 & 14.00 & 14.07 & 14.12 \\
\hline Manufacturing of various products & 17.10 & 17.14 & 16.17 & 16.20 & 16.63 \\
\hline Electricity, water and gas & 14.74 & 14.77 & 14.15 & 14.13 & 14.40 \\
\hline Building industry & 14.13 & 14.09 & 13.69 & 13.73 & 13.87 \\
\hline
\end{tabular}

Source: Authors' calculations with CUCl database (n.d.).

Figure 12: TFP for the first three sectors in terms of value added

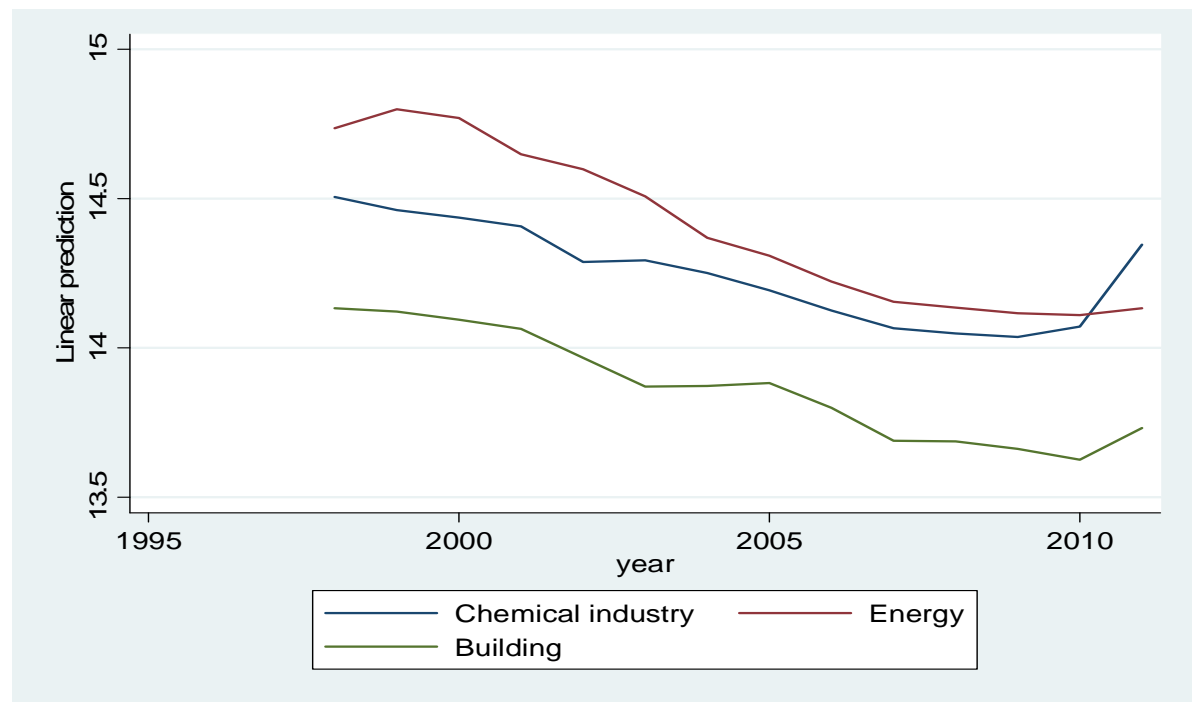

Source: Authors' calculations with CUCI database (n.d.). 
Over the thirteen-year period (from 1998 to 2011) the highest average TFP was registered in the manufacturing of other foods (16.84), manufacturing of various products (16.63), production of rubber products (16.12) and metallurgy, foundry and foundry services (15.79).

At the same time, the main sectors in terms of share in value added and of the number of employees do not fare very well in terms of TFP. The average TFP over the above-mentioned period was only 13.87 for the building sector and 14.40 for the energy producing sector and 14.25 for the chemical industry.

Figure 12 shows the patterns of the first three branches that contribute to the Senegalese value added and employment. The TFP rates show a downward trend in all these industries until 2010 when they seem to become linear and stable for the energy sector and to start a increasing trend for the chemical and building sectors.

Comparatively Figure 13 shows the evolution in terms of TFP of the three most dynamic sectors in terms of TFP over the period ranging from 1998 to 2011.

A very irregular variation of the TFP in these industries is obvious. TFP rates seem to be very unstable and volatile. Whereas a peak was reached by the other foods sector in 2004, the others subsectors mainly experienced a downward trend with a reverse tendency starting from 2010 . The sector of production of rubber products moved one TFP point between 1999 and 2008.

The evolution of Senegal's main exporting sectors, as well as the low performance in terms of education and electricity supply as explained further on in this section are the three factors that we emphasize to explain the evolution of the TFP.

Figure 13: TFP for the most dynamic sectors over the period 1998-2011

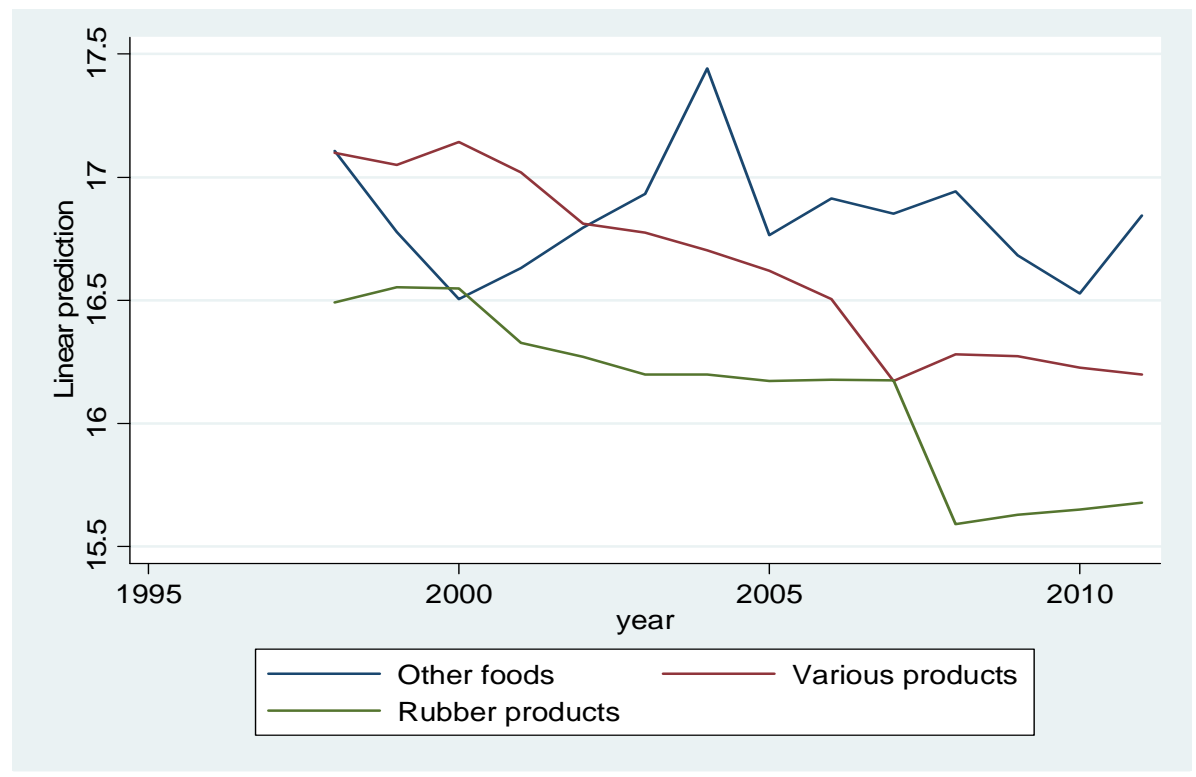

Source: Authors' calculations with CUCI database (n.d.).

\subsection{Education in Senegal}

Over the past 15 years, Senegal has made considerable efforts with regard to education policies. Between 2000 and 2009, education expenditure rose from 3 per cent to 6 per cent of GDP, i.e., 40 per cent of the total budget (African Economic Outlook). In the context of sub-Saharan Africa 
and other neighbouring countries, where the average is 4 per cent of GDP, this figure of 6 per cent can be considered to be high (Table 7).

Table 7: Education expenditure in selected African countries (\% of GDP)

\begin{tabular}{lc}
\hline & Education expenditure (\% GDP) \\
\hline Senegal & 6.0 \\
SSA & 4.0 \\
Mali & 4.4 \\
Ghana & 5.4 \\
Burkina Faso & 4.6 \\
Niger & 4.5 \\
Rwanda & 4.1 \\
Cameroon & 3.7 \\
Kenya & 7.0 \\
\hline
\end{tabular}

Source: CIA World Factbook (2010).

In 2009, 47 per cent of total education expenditure was allocated to primary education, 27 per cent to secondary education and 24 per cent to higher education. These rates are close to the average rates for sub-Saharan Africa and neighbouring countries (see Figure 14).

Figure 14: Breakdown of education expenditure by levels in selected African countries, 2009

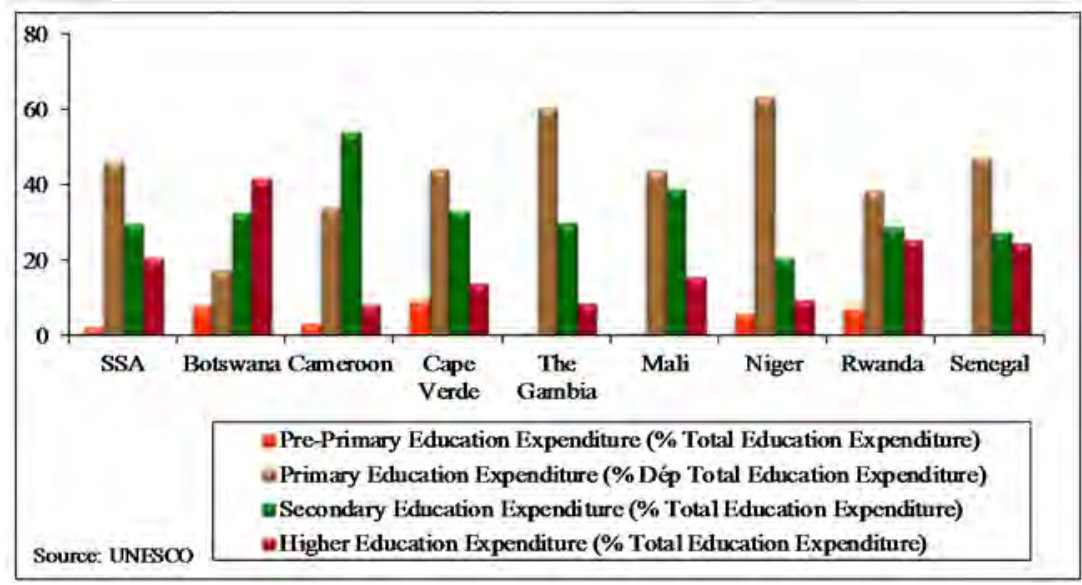

Source: UNESCO (2007).

Table 8: Illiteracy rates in selected African countries, 2009

\begin{tabular}{lc}
\hline & Adult illiteracy rate (\%) \\
\hline Cape Verde & 15.2 \\
Comoros & 25.85 \\
The Gambia & 53.5 \\
Kenya & 12.99 \\
Liberia & 40.95 \\
Nigeria & 39.18 \\
Senegal & 50.3 \\
SSA & 37.72 \\
Zambia & 29.12 \\
\hline
\end{tabular}

Source: World Bank (2010). 
The importance of investment in human capital is fully justified, as the requirements are considerable. Illiteracy affected half of the population in 2009, a much higher level than that observed in sub-Saharan Africa, where an average of 37.7 per cent of the people are concerned (Table 8). Women are particularly affected (61 per cent) as they attend school for a shorter period.

Table 9: Illiteracy rates in the population aged 15-years and over, by area of residence and gender

\begin{tabular}{lccc}
\hline Area of residence & All & Men & Women \\
\hline All & 62.2 & 50.9 & 71.8 \\
Urban areas & 44.5 & 33.6 & 53.9 \\
Rural areas & 76.7 & 65.2 & 86.3 \\
\hline
\end{tabular}

Source: Authors' calculations based on the ESAM-II Survey (n.d.).

The second Senegalese Household Survey (ESAM-II) shows that inequality in access to education is also a regional problem. Rural areas are much more affected by illiteracy: 76 per cent of people (86 per cent of women) in rural areas are illiterate (Table 9).

Between 1988 and 2009, the literacy rate rose from 26.9 per cent to 49.7 per cent for the adult population marking a significant improvement. The literacy rates for the younger cohorts also rose between 1988 and 2009 from 37 per cent to 65 per cent. This improvement was evident for both genders; whereas the rates for young men rose from 49 per cent to 74 per cent, the rates for young women increased from 28 per cent to 56 per cent.

Figure 15: Literacy trends, 1988-2009
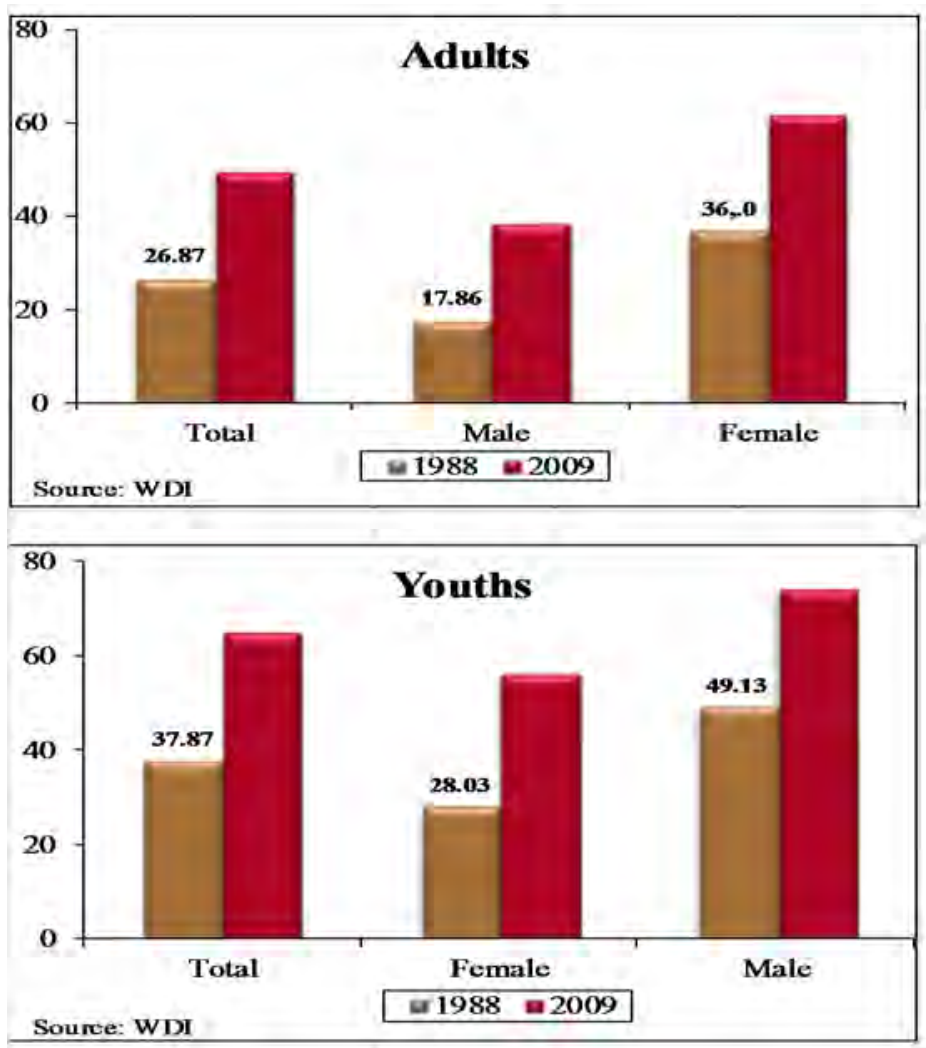

Source: World Bank (2010).

The efficiency of education expenditure is assessed according to two criteria. Internal efficiency depends on the ability to retain the maximum number of pupils in school (enrolment rate), and 
the results obtained by pupils (that can be measured by the proportion of repeaters) as well as by available resources (teachers, classes, equipment, etc.). External efficiency corresponds to the match between the provision of education and the needs of the market.

The average number of years of school ( +15 years old) in 2009 was 4.05. Close to the average for sub-Saharan African countries, this rate is low when compared to those of Latin America or East Asia or even such SSA countries as Ghana, Kenya and Zambia. Enrolment rates are even lower for the female population over 15-years: about 3 years (Figure 16).

Gross enrolment rates in primary education rose from 68 per cent in 1998 to 86 per cent in 2009. However, these rates are below the average SSA rates (78 per cent in 1998 and 102 per cent in 2009) and those of certain comparative countries (Figure 18). The primary enrolment rates are virtually identical for both genders: 84 per cent for boys and 88 per cent for girls.

Enrolment by level is not very different from that observed in countries with similar levels of development as is shown in Figure 17. However, in more developed countries like Cape Verde and Indonesia, the enrolment rates at all levels are significantly higher.

Figure 16: Average number of years of school (+15 years old) for Senegal and comparative countries, 2010 (total and women)

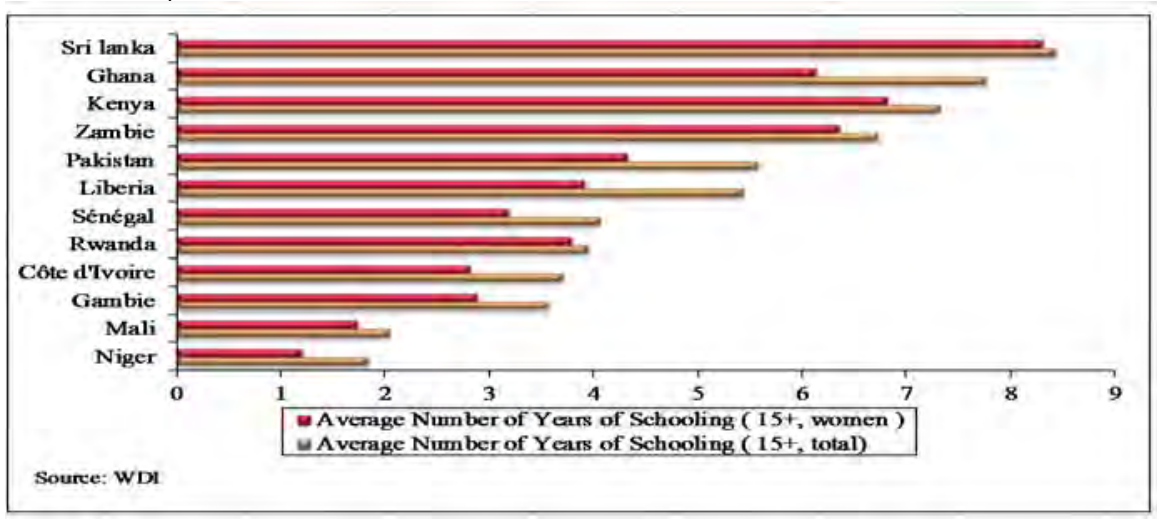

Source: World Bank (2010).

Figure 17: Primary education enrolment rates for selective countries, 2009 (total, male and female)

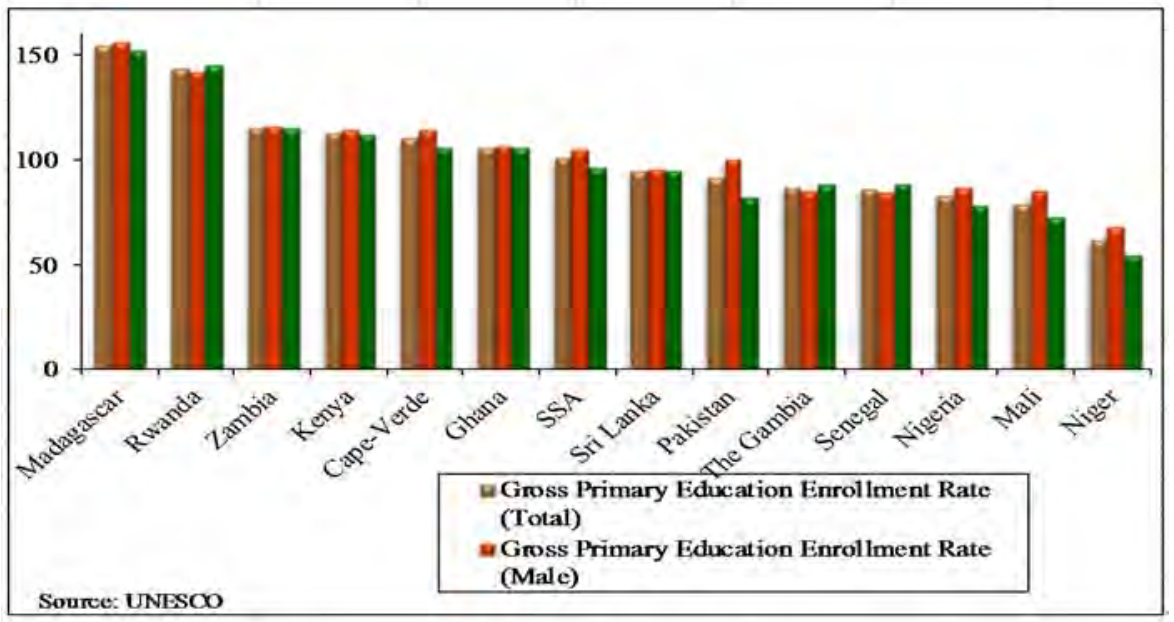

Source: UNESCO (2007). 


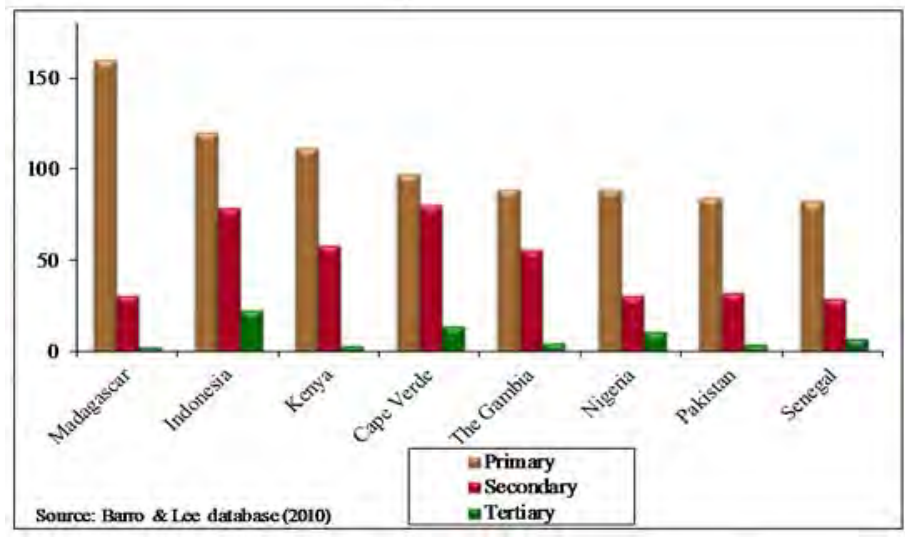

Source: Barro and Lee database (2010).

It is also worth noting that the proportion of children completing primary education is rising more slowly than the enrolment rates (58.4 per cent in 2008). The rate attained in 2008 falls far short of the 2015 target rate of 83 per cent set by the World Bank and is considerably lower than the rates recorded by West African countries (Ghana 73 per cent, The Gambia 91 per cent, Mali 79 per cent and Cape Verde 85 per cent). Further efforts are required in this area. The secondary education enrolment rate is much lower for both genders. It was 31.4 per cent in 2008 (34.9 per cent for boys and 27.7 per cent for girls). Enrolment in higher education did not exceed 8.3 per cent in 2008 (10 per cent for men and 6 per cent for women). These rates are considered low even though they are close to the average of rates for SSA (34.8 per cent for secondary education and 6 per cent for higher education).

Table 10: Secondary and higher education enrolment rates for Senegal and SSA, 2008

\begin{tabular}{llcc}
\hline & & Senegal & SSA \\
\hline Gross secondary enrolment rates & Total & 31.4 & 34.8 \\
& Male & 34.9 & 39 \\
& Female & 27.7 & 30.5 \\
Gross higher education enrolment rates & Total & 8.3 & 6 \\
& Male & 10.5 & 7.6 \\
& Female & 6 & 4.8 \\
\hline
\end{tabular}

Source: UNESCO (2007).

Using quintiles of per capita expenditure as a proxy for household living standards, an analysis of the relationship between gross enrolment rates and household living standards, carried out by the Forecasting and Statistics Department in Senegal following the second Senegalese Household survey (ESAM-II) showed that the wealthiest households and/or those living in urban areas educate their children better. This result confirms the problem of regional disparities. 
Table 11: Differential variations of the gross enrolment rate according to area of residence

\begin{tabular}{lccc}
\hline & \multicolumn{3}{c}{ Area of residence } \\
\cline { 2 - 4 } Quintiles of per capita expenditure & Total country & Urban & Rural \\
\hline Top quintile & 51.0 & 54.1 & 50.1 \\
2nd quintile & 49.7 & 62.8 & 46.1 \\
3rd quintile & 58.9 & 78.4 & 47.5 \\
4th quintile & 70.9 & 79.4 & 55.5 \\
Bottom quintile & 83.4 & 84.9 & 45.3 \\
\hline
\end{tabular}

Source: Authors' calculations based on ESAM-II Survey (n.d.).

The proportion of repeaters has fallen although it remained higher than in other developing countries, reflecting low internal efficiency which could negatively affect the quality of human capital in Senegal. The percentage of repeaters in primary education fell from 13.61 per cent in 2000 to 7.68 per cent in $2008 .^{1}$ At secondary level, the proportion of repeaters fell from 16.55 per cent to 14.45 per cent over the same period.

Table 12: Comparison of the proportion of repeaters, 2008

\begin{tabular}{lc}
\hline Countries & Proportion of repeaters in primary education, \% \\
\hline Cape Verde & 11.59 \\
Comoros & 24.43 \\
The Gambia & 5.422 \\
Indonesia & 2.910 \\
Madagascar & 19.66 \\
Senegal & 7.68 \\
Sri Lanka & 0.824 \\
Zambia & 5.882 \\
Average for Francophone Africa & 16.53 \\
\hline
\end{tabular}

Source: UNESCO (2007).

The external efficiency of education depends on the balance between supply and demand. In one way, the relative weakness of secondary and higher education enrolment is due to the fact that the job market in Senegal is more open to job seekers with primary, secondary or vocational levels of education. According to Table 13, the most profitable investments are at primary level $(24$ per cent), and the return on technical education is higher than that on middle education. On the other hand, the efficiency of higher education has not been proven.

The current situation in Senegal reflects an excess supply of graduates, and competition for formal jobs is forcing some to turn to the informal sector, taking jobs below their qualifications or even to emigrate (Foko et al. 2004). This is a real sign of the external inefficiency of education or of an imbalance between job supply and demand.

1 The indicative framework of the Education for All- Fast Track Initiative recommends a repeater rate of about 10 per cent. 
Table 13: Rates of return to education in Senegal, \%

\begin{tabular}{lccc}
\hline & & \multicolumn{2}{c}{ Private } \\
\cline { 3 - 4 } Level of education & Social & Formal sector Informal sector \\
\hline Primary school certificate / no diploma & 24 & 11 & 29 \\
Secondary school diploma / primary school certificate & 16 & 18 & 27 \\
Technical / vocational education diploma/primary school certificate & 17 & 20 & 38 \\
Baccalauréat(BA) / Secondary school diploma & 11 & 14 & 29 \\
Licence / Baccalauréat(BA) or above & NPV<0 & 0,1 & $-0,2$ \\
\hline
\end{tabular}

Source: UNESCO (2007).

While the labour market participation rate in Senegal remained stable between 1990 and 2009 (76.9 per cent in 1990 and 77.5 per cent in 2009), the unemployment rate rose from 8 per cent to 14 per cent of the work force. This unemployment rate decreases with age and mainly affects the urban population. ${ }^{2}$ It is rising but not linear with the level of education, reaching its highest level for those who left high school without A-levels, followed by those who have a higher level of education. Young graduates are hit the hardest by unemployment and are tempted to emigrate.

Figure 19: Labour market participation rate (population aged 15-64)

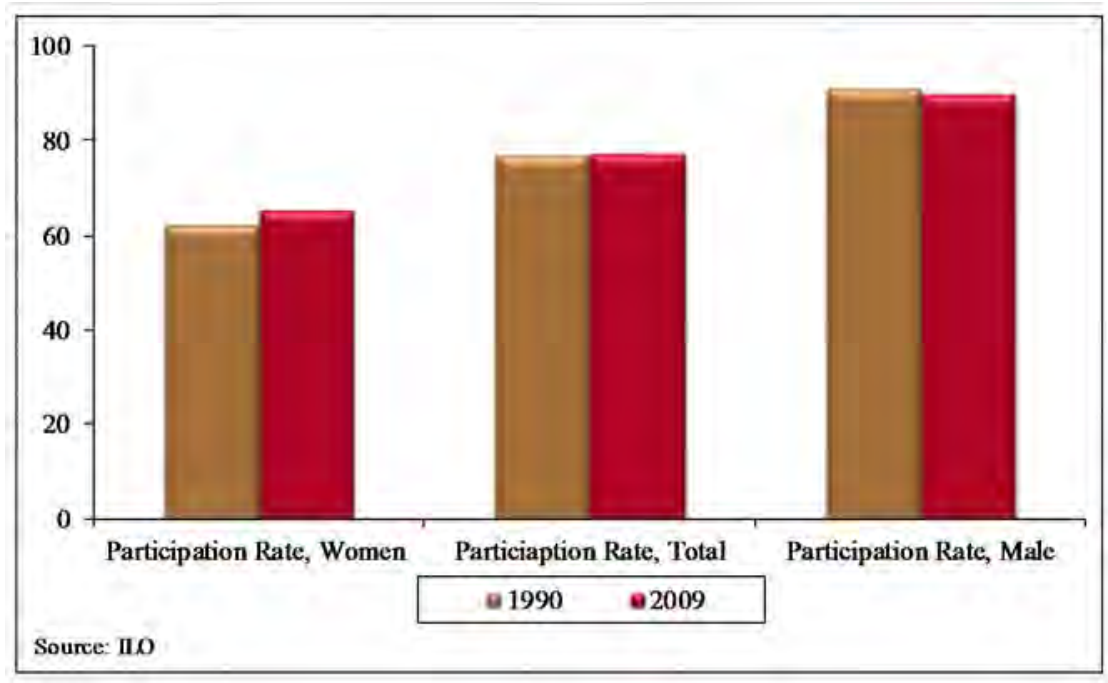

Source: ILO (various years).

According to the 2001 Senegalese Household Survey (ESAM II), 68 per cent of migrants are between 15 and 34 years old and 94 per cent between 15 and 54 years old. Skilled workers represent 24.1 per cent of the migrant stock (Dia 2006). Also 17.7 per cent of the population with a higher education level emigrated in 2001 (Docquier and Marfoukb 2005). Clemens and Petterson (2007) confirm the brain drain diagnosis: 51 per cent of Senegalese doctors and 27 per cent of nurses emigrated over the 1995-2005 period, mainly to France.

Literacy levels of the adult population remain low, especially among the rural population, despite a significant improvement between 1988 and 2009, when the literacy rate rose from 26.9 per cent to 49.7 per cent for the adult population. Illiteracy continued to affect half of the population in

2 The risk of unemployment is four times higher in urban areas than in rural areas. 
2009 and women in particular are affected by this phenomenon (61 per cent). Special efforts should be made to improve the literacy level for women in rural areas.

Figure 20: Loss of sales as a result of power outages by sector

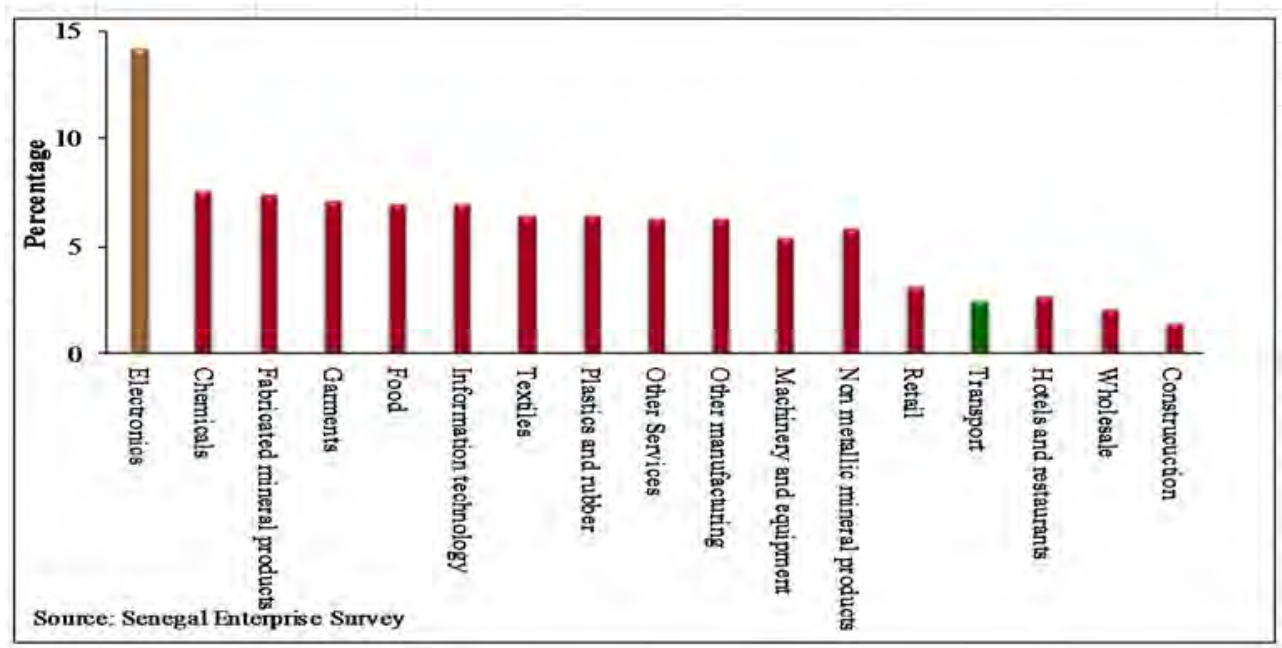

Source: Authors' calculations based on the ESAM-II Survey (n.d.).

Figure 20 gives the percentage of annual sales lost as a result of a power outage by sector of activity. The average loss is 4.6 per cent with 7.5 per cent for small enterprises and 7 per cent for large enterprises. The worst affected firms are in the electronics sector. Successive power outages and cuts have led to the installation of electric generators by firms. These are much more expensive than grid-supplied electricity. Thus, to offset the shortfall in electricity, over 61 per cent of manufacturing enterprises in Senegal (35.3 per cent in Uganda and 38.2 per cent in Zambia) have had to acquire generators to offset this shortfall (see Table 14).

Table 14: Electricity indicators for Senegalese firms

\begin{tabular}{lc}
\hline Indicators & Percentage \\
\hline Loss due to outages & 5.1 \\
Frequency of power outages (in days) & 31.5 \\
\% of firms owning a generator & 61.6 \\
Days to obtain an electrical connection (after application) & 12.4 \\
\hline
\end{tabular}

Source: World Bank (n.d.). 
Figure 21: Supply of electricity for households by area of residence

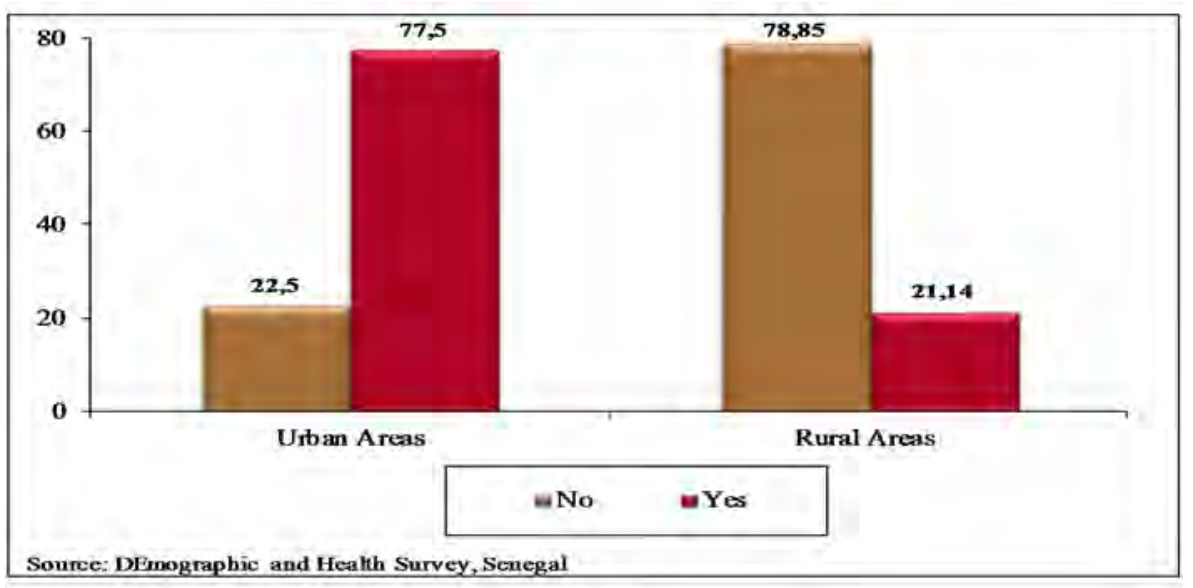

Source: AICD (2012).

Figure 22: Insufficiency of prevailing rates to recover current electricity costs in Senegal

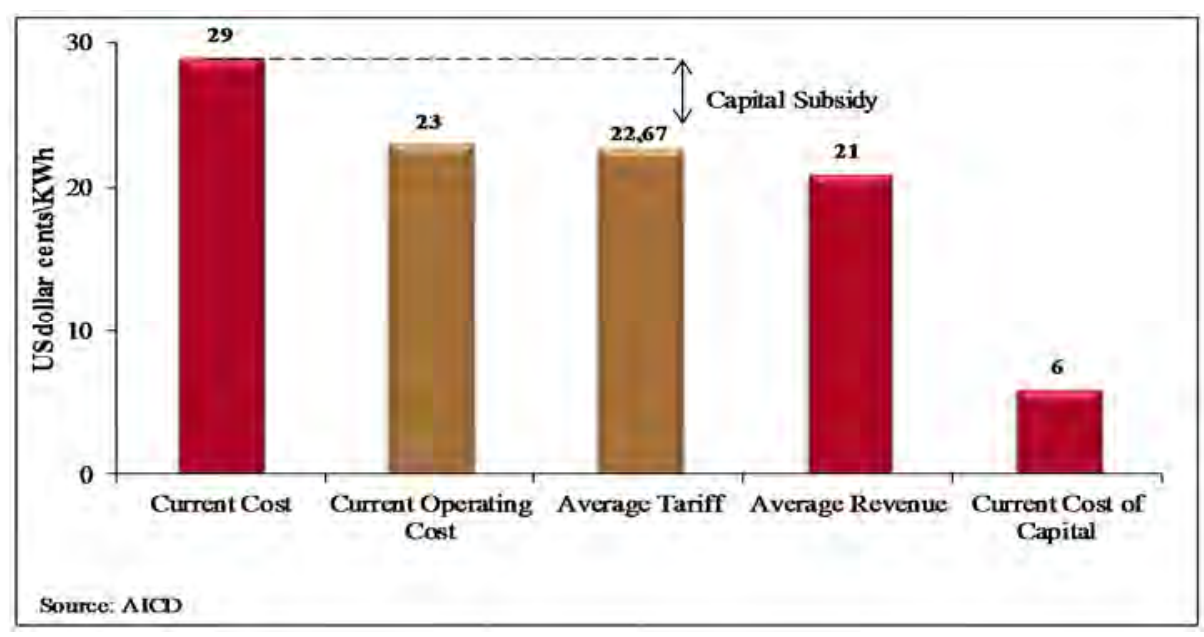

Source: AICD (2012).

Between 2000 and 2009, generation capacity grew from 365 MW to 510 MW while demand kept growing at a rate of 25-30 MW per year. This was undoubtedly a significant increase in generation achieved by SENELEC but it still does not meet the ever rising demand. In addition to the problem of high demand for electricity that SENELEC cannot meet, the company is faced with other problems. Its power generation and transmission facilities are obsolete, preventing the company from effectively meeting the growing demand and resolving power disruptions.

To solve this, electricity rates rose in 2006 to the highest levels in West Africa (Table 15) and SSA: almost 60 per cent higher than in Côte d'Ivoire: CFAF 46/KWh in high voltage compared to CFAF 29 in Côte d'Ivoire. 
Table 15: Average electricity rates in West Africa

\begin{tabular}{lc}
\hline & Price (US $\$$ /KWh) \\
\hline Côte d'Ivoire & 13.11 \\
Togo & 14.92 \\
Burkina Faso & 30.0 \\
Mali & 19.9 \\
Niger & 14.07 \\
Senegal & 22.7 \\
Nigeria & 4.2 \\
Benin & 14.28 \\
The Gambia & 27.33 \\
Liberia & 43.0 \\
Ghana & 8.93 \\
\hline
\end{tabular}

Source: AICD (2012).

Meeting Senegal's infrastructure gap would require US $\$ 1.8$ billion per year over the next ten years, i.e., about 20 per cent of GDP. The highest allocations should be to electric power generation infrastructure (Briceno-Garmendia 2011). These needs are high in comparison to those of the other countries in the region (see Figure 23). At present, Senegal allocates US\$911 million per year to its infrastructure (i.e., 11 per cent of GDP).

Control of electric power wastage because of frequent power outages (representing US $\$ 312$ million per year) would certainly enable the country to improve the infrastructure situation. In this respect, cost recovery in the electricity sector is one of the challenges to be taken up.

Figure 23: Average electricity rates in Africa

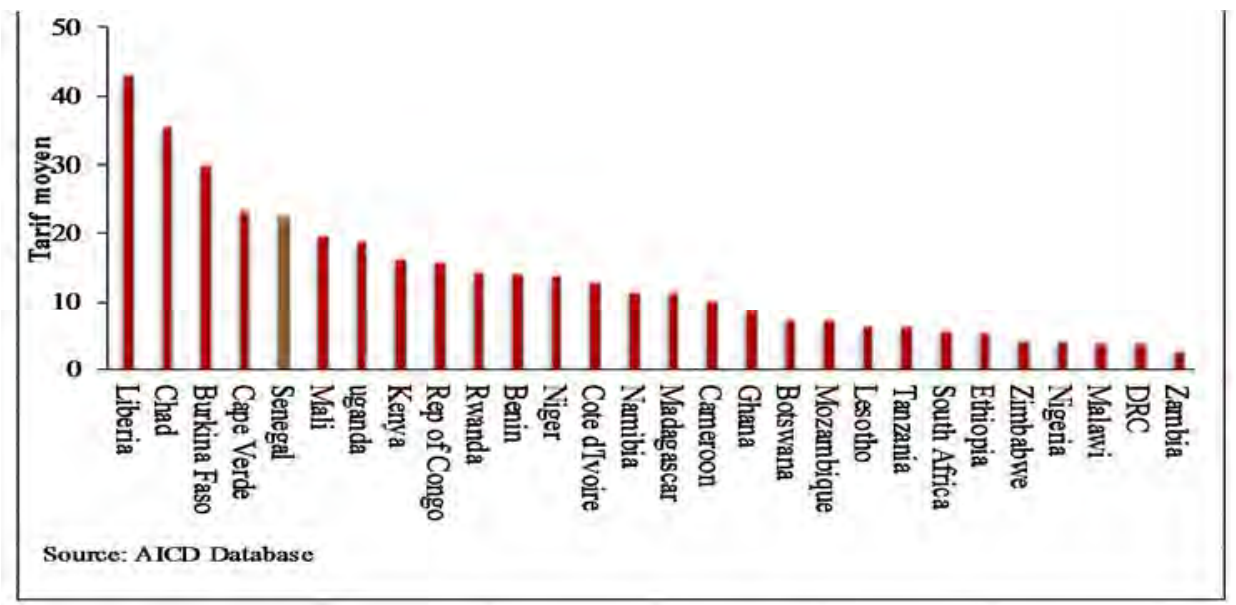

Source: AICD (2012). 
Figure 24: Financing the gap in electric power generation (in \% of GDP) in Senegal and neighbouring countries

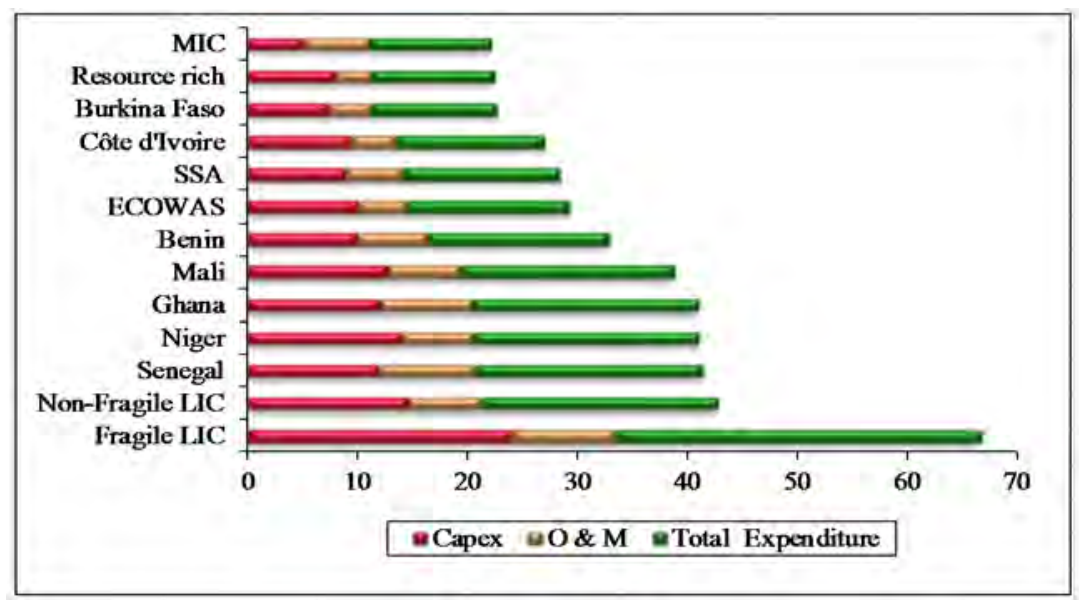

Notes: MIC: middle-income countries, LIC: low income countries, CAPEX: capital expenditure, O \& M: Operation and maintenance.

Source: AICD (2012).

\section{$4 \quad$ Emerging policy issues}

Senegal belongs to the intermediate category of sub-Saharan countries characterized by insufficient growth rates, particularly after the 1990s decade of deregulation, the 1994 devaluation of the CFA franc and debt relief programmes. The weakness of investment partly reflects to the scale of public investments whose impact on growth in the short-term is difficult to assess. But beyond the publicprivate split, despite investment increasing in the 2000s from a low level, it did not revive the growth. The resulting falling 'returns' may be explained by the economy's dualism, which reduces the absorptive capacity of supplementary financing sources and the attractiveness for potential investors.

The TFP trend highlights the dependency of Senegal's growth on agriculture, which employs a vast majority of the population. The main obstacle is the economy's persisting dualism characterized by the size of the informal sector and its attendant factors: inadequate economic diversification, weak institutions that do not motivate workers to leave the informal sector, or even to have access to formal financing.

The review of the Senegalese exports reveals an over-concentration and a low level of sophistication in its exports. These two characteristics clearly apply to a country whose level of development remains low, with a slow diversification process, and which faces obstacles of an essentially regulatory nature. One should recognize, however, that the actual level of diversification is not far-off from what it could/should be, given that the country's level of economic development/GDP per capita. Therefore, room for manoeuvre is quite limited.

One clear objective should be for Senegal to improve the infrastructure, more particularly the improvement of electricity supply. Frequent power outages represent a source of waste with a high cost. But efforts made by the country to this end are not negligible as 11 per cent of GDP is spent on the infrastructure sector. The main problem is that electricity is allocated insufficient quantities, which is the main impediment to industrial growth. Limited supply and frequent outages are identified in the surveys as one of the main obstacles to the development of the country's industrial activities and economic growth. 
Privatization might be a possible solution, provided that electricity rates are sufficiently attractive for investors. Improving the supply and the financial performance of SENELEC (Senegal National Electricity Company) whose costs are too high should be a main issue. The increase in private management in the infrastructure sector has emerged as a logical response to several constraints: search for enhanced efficiency, limited public resources, and desire to attract foreign investors. Although this strategy has achieved considerable success especially in the transport and water supply sector, partial privatization of the electricity sector has not produced the expected results. The reasons need to be analysed before undertaking further privatization.

Another key issue is the drive on education. Its focus should be on primary education, and technical training where the returns are higher. Returns to higher education are low because the job market in Senegal is more open to job seekers with primary, secondary and technical levels of education than to university graduates. The job market seems to favour labour with low or intermediate qualifications with a primary school certificate or a technical diploma.

The Senegalese educational system is sub-optimal as it offers training, which does not meet the requirements of the labour market. The mismatch between supply and demand (too many overqualified graduates) has resulted in a high unemployment rate and braindrain. Considerable efforts are required to improve the Senegalese human capital, especially in the areas of secondary and university education for the country to rapidly achieve a quality of human capital comparable to the emerging countries. 


\section{Aacronyms}

ANSD National Agency of Statistics and Demography

CET common external tariff

CUCI Centre Unique de Collecte de l'Information

FDI foreign direct investment

ESAM Senegalese Household Survey

NPA new agricultural policy

NPI new industrial policy

PAMLT Senegal's structural adjustment programme

PCS community solidarity levy

PRI industrial redeployment policy

RS statistical tax

SCA accelerated growth strategy

SDSP private sector development strategy

TDP digressive protection tax

TFP total factor productivity

WAEMU West African Economic and Monetary Union

ZFID Dakar Industrial Free Trade Zone 


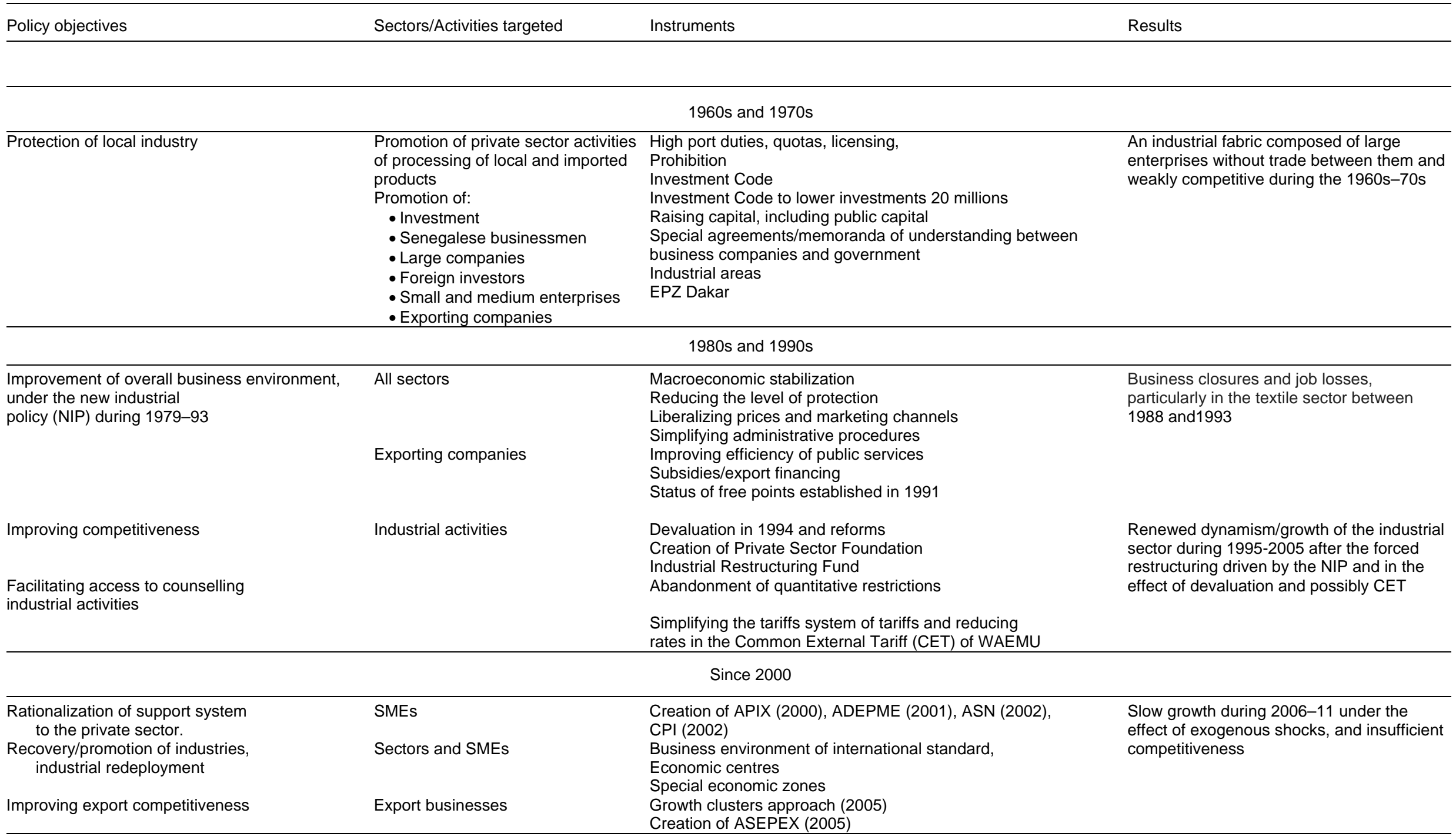

Source: Authors' compilation. 


\section{References}

African Development Bank (AfDB) (2012). 'Senegal Country Growth Diagnosis'. Tunis: AfDB.

African Economic Outlook (2009). 'Country Senegal'. Issy les Moulineaux: OECD Centre. Available at: http: www.africaneconomicoutlook.org/en/countries/west-africa/senegal/

Agence de Développement et d'Encadrement des Petites et Moyennes Entreprises (ADEPME) 2001. 'Data'. Dakar: ADEPME.

Agence Nationale de la Statistique et de la Démographie (ANSD), Centre Unique de Collecte de l'Information (CUCI). (various years). 'Data Base, 1998-2011'. Dakar: ANSD.

Agence pour la Promotion de l'Investissement et des Exportations (APIX) (2000). Dakar: APIX.

AICD (Agence Nationale de la Statistique and ICF International) (2012). '2010-11 Senegal Demographic and Health and Multiple Indicators Survey: Key Findings'. Calverton, MD: ANSD and ICF International.

Association Sénégalaise de Normalisation (ASN) (2002). 'Data'. Dakar: ASN.

Babacar, F., A. C. Touré; A. Demba Lom, and M. El Bachir Wade (1995). Réseau de Recherche sur les Politiques Industrielles en Afrique, 4. Dakar: CODESRIA.

Barro, R. J., and J. W. Lee (2013). 'A New Data Set of Educational Attainment in the World, 19502010’. Journal of Development Economics, 104: 184-98.

Berthélémy, J.-C., A. Seck, and A. Vourc'h (1996). Economic Growth in Senegal: A Lost Opportunity. Paris: OECD.

Briceno-Garmendia, C., C. Torres, and C. Dominguez (2011). 'Senegal's Infrastructure: A Continental Perspective'. Policy Research Working Paper 5817. Washington, DC. World Bank.

CIA World Factbook (2010). Available at: www.cia.gov/library/publications/the-worldfactbook/index.html.

Clemens, M., and G. Pettersson (2007). 'New Data on African Health Professionals Abroad'. CGD Report 95. Washington, DC: Center for Global Development.

Corruption Perceptions Index (CPI) 2002. Available at: http://www.transparency.org/research/cpi/overview

CUCI (Centre Unique de Collecte de l'Information) (n.d.). 'CUCI Database'. Dakar: CUCI.

Dia, I. A. (2006). 'Profile of International Migration from Senegal'. Report for the MRF Regional Office for West and Central Africa. Dakar: International Organization for Migration.

Docquier, F., and A. Marfoukb (2005). 'International Migration by Educational Attainment (19902000)'. Sussex: Centre for Migration, Globalization and Poverty, University of Sussex.

ESAM-II Survey (Senegalese Household Survey) (n.d.). Dakar.

Foko, B., F. Ndem, and N. Reuge (2004): 'Economic Aspects of External Efficiency of Education in Senegal'. UNESCO Education Sector Analysis, October. Dakar Pole: UNESCO.

International Labor Organisation (ILO) (various years). 'Data, 1990-2009'. Geneva: ILO.

Imbs, J., and R. Wacziarg (2003). 'Stages of Diversification'. The American Economic Review, 93(1): 63-86.

IMF (2012). Report 12/337. November. Washington, DC: IMF. 
IOM (International Orgnaization for Migration) (2006): 'Profile of International Migration from Senegal'. Dakar: IOM. Available at: www.iom.int/cms/en/sites/iom/home/what-wedo/migration-policy-and-research/migration-research-1/migration-profiles.html

L’Agence Sénégalaise de Promotion des Exportations (ASEPEX) (2005). 'Data'. Dakar: ASEPEX.

Maurel, M., and M. Seghir (2014.). 'The Main Obstacles to Firm Growth in Senegal'. African Development Bank Group Working Paper 197. Tunis: AfDB.

Ministère de l'Economie et des Finances (1988). 'Programme D'ajustement du Secteur Financier, 1989-1991'. Dakar.

Ministère de l'Economie et des Finances (2012). 'Stratégie Nationale de Développement Économique et Social'. October. Dakar: Ministère de l'Economie et des Finances.

Ministère de l'Industrie et de l'Artisanat (2005). 'Lettre de Politique Sectorielle de Développement de l'industrie: la Politique de Redéploiement Industriel. Dakar.

Ministère des Mines, de l'Industrie, de l'Agroindustrie et des PME (2010). Lettre de Politique Sectorielle des PME'. Dakar: Ministère des Mines, de l'Industrie, de l'Agroindustrie et des PME

Republic of Senegal/UNDP (1997). 'L’industrie Sénégalaise de 1992 à 1995’. Dakar : Republic of Senegal/UNDP.

Torres, C., C. Briceno-Garmendia, and C. Dominguez (2011). 'Senegal's Infrastructure: A Continental Perspective'. Policy Research Working Paper 5817. Washington, DC: World Bank.

UNESCO (2007). 'The Efficiency of Education in Senegal: An Economic Analysis'. UNESCO Country Note 4. Dakar: UNESCO.

World Bank (2010). 'World Development Indicators'. Washington, DC: World Bank. Available at: http://data.worldbank.org/data-catalog/world-development-indicators/wdi-2010

World Bank (n.d.). 'Enterprise Survey'. Available at: /www.enterprisesurveys.org/. 